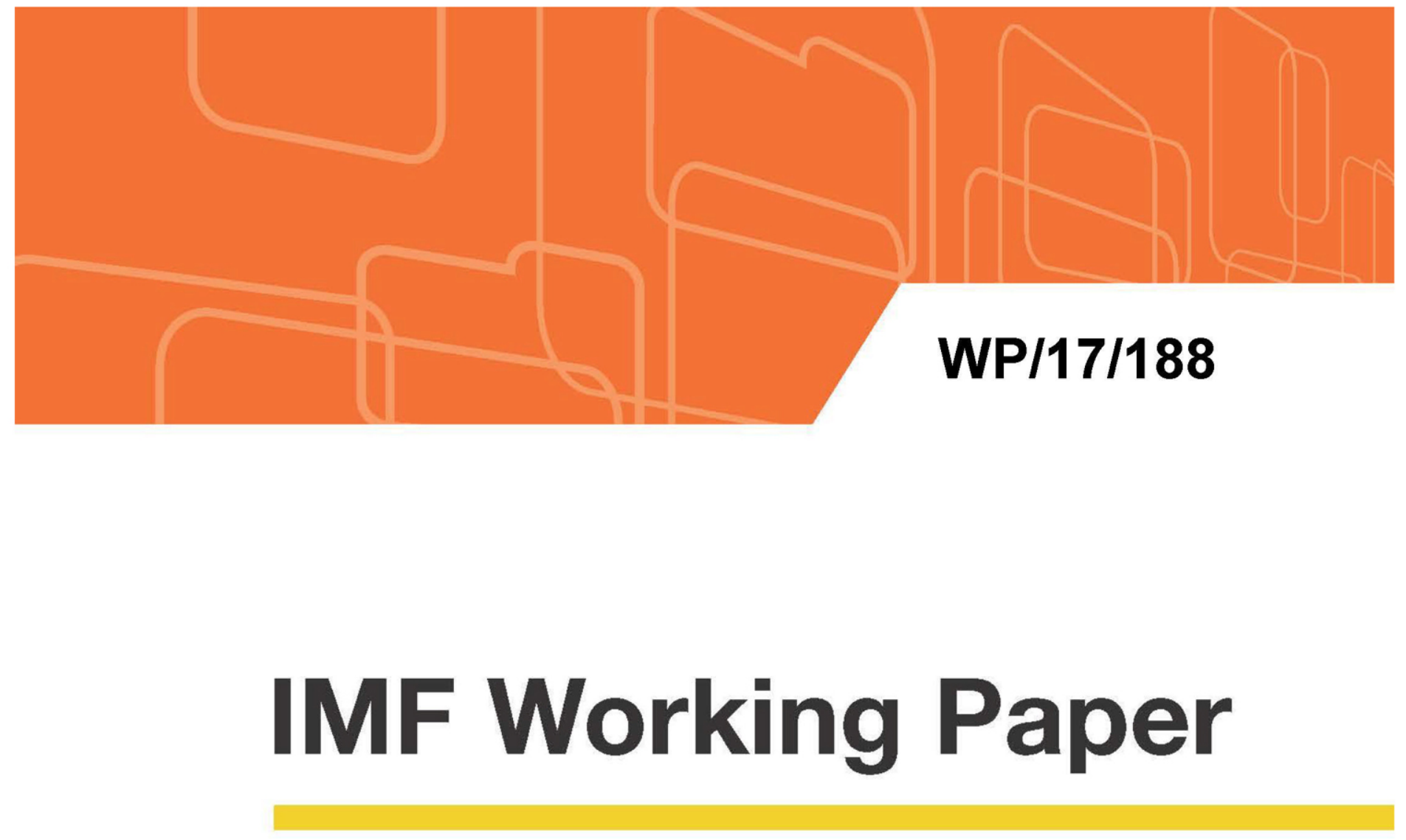

\title{
Bankruptcy Technology, Finance, and Entrepreneurship
}

by Nelson Sobrinho

IMF Working Papers describe research in progress by the author(s) and are published to elicit comments and to encourage debate. The views expressed in IMF Working Papers are those of the author(s) and do not necessarily represent the views of the IMF, its Executive Board, or IMF management.

I N T E R N A T I O N A L M O N E T A R Y 


\title{
WP/17/188
}

\section{IMF Working Paper}

\section{Bankruptcy Technology, Finance, and Entrepreneurship}

\author{
by Nelson Sobrinho
}

IMF Working Papers describe research in progress by the author(s) and are published to elicit comments and to encourage debate. The views expressed in IMF Working Papers are those of the author(s) and do not necessarily represent the views of the IMF, its Executive Board, or IMF management.

I N T E R N A T I O N A L M O M N E T A R Y F F U N D 


\title{
IMF Working Paper
}

Strategy, Policy and Review Department

\section{Bankruptcy Technology, Finance and Entrepreneurship ${ }^{1}$ \\ Prepared by Nelson Sobrinho}

Authorized for distribution by Mark Flanagan

August 2017

\section{IMF Working Papers describe research in progress by the author(s) and are published to elicit comments and to encourage debate. The views expressed in IMF Working Papers are those of the author(s) and do not necessarily represent the views of the IMF, its Executive Board, or IMF management.}

\begin{abstract}
Using an overlapping-generations growth model featuring financial intermediation, I find that inefficiencies in technology to deal with private debt distress (bankruptcy technology), and obstacles to entrepreneurship (high costs of doing business) have significant negative effects on the income per capita and welfare of developing countries. These inefficiencies may also interact in perverse ways, further amplifying the negative effects in the long run. The results provide strong rationale for structural reforms that simultaneously speed up the resolution of private sector insolvency, improve creditor protection, and eliminate obstacles to entrepreneurship.
\end{abstract}

JEL Classification Numbers: D23; D91; G33; O16.

Keywords: Agency Costs; Creditor Rights; Bankruptcy; Financial Intermediation.

Author's E-Mail Address: nsobrinho@imf.org.

\footnotetext{
${ }^{1}$ I am very grateful to Mark Flanagan for his guidance and significant suggestions. I thank Ali Abbas for his very useful comments. I also thank the participants of a LACEA conference and Central Bank of Brazil seminar for their feedback on an older and preliminary version of the paper. All remaining errors are mine.
} 


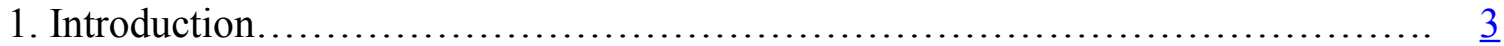

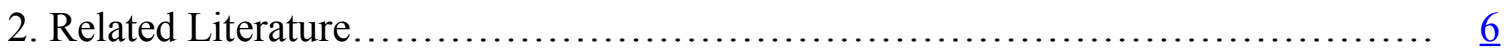

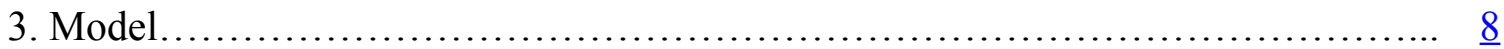

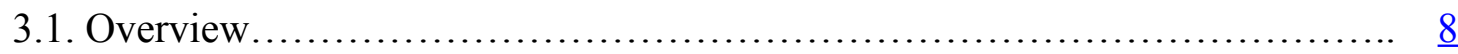

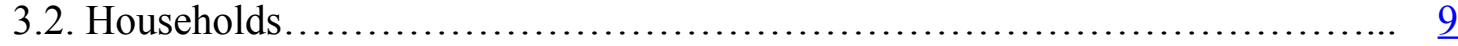

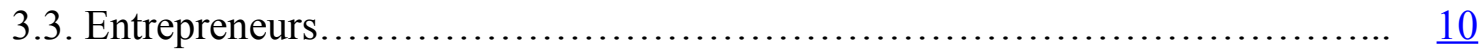

3.4. Banks and Loan Contract........................................... 11

3.5. Credit Market Outcomes and Supply of Capital.......................... $\quad \frac{14}{15}$

3.6. Equilibrium with Financial Intermediation............................... 15

3.7. Self-Finance Equilibrium............................................. 16

3.8. Steady State and Welfare.............................................. $\quad 17$

4. Functional Forms and Parameters..........................................

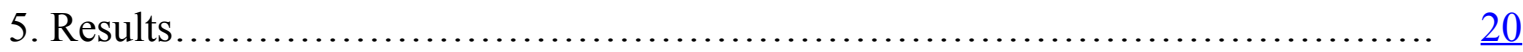

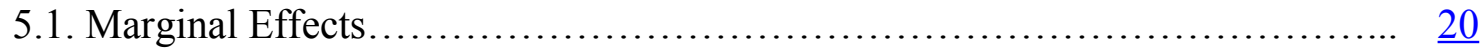

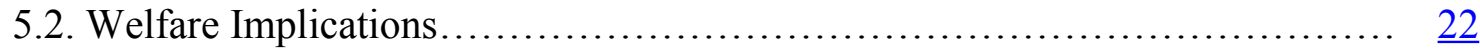

5.3. Perverse Interactions.....................................................

5.4. Bankruptcy Technology and Capital Flight............................. $\underline{23}$

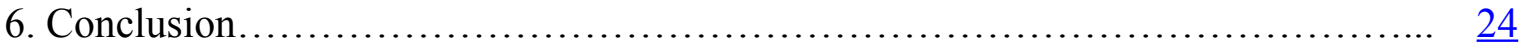

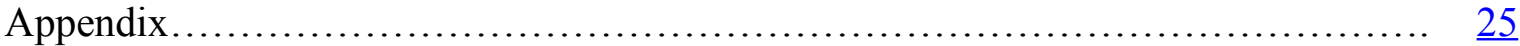

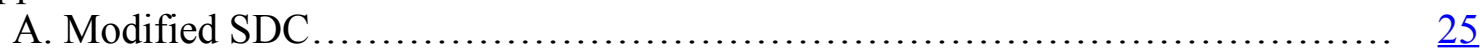

B. Properties of the Loan Contract............................................. $\frac{27}{27}$

C. Properties of the Capital Supply Correspondence........................... $\underline{28}$

D. Alternative Deposit Supply Function....................................

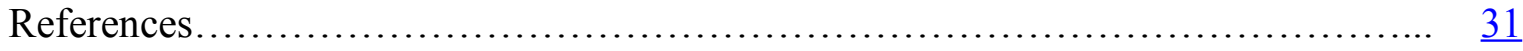

\section{Tables}

1. Cost of Doing Business and Bankruptcy Technology Across Countries.......... $\underline{35}$

2. Baseline Parameters.......................................................... $\quad 35$

\section{Figures}

1. Cost of Doing Business, Bankruptcy Technology and Economic Outcomes...... $\quad \underline{36}$

2. Sequence of Events for Time-t Young Cohorts............................... $\quad \underline{36}$

3. Payment Function of the Bank........................................... $\quad \frac{37}{37}$

4. Expected Payoffs (case of unit investment)................................ $\quad \frac{37}{37}$

5. Credit Market Equilibrium (case of unit wage rate)........................ $\quad \underline{37}$

6. Marginal Effects of the Cost of Running a Project ( $\tau$ ), Bankruptcy Cost $(\kappa)$, and $\underline{38}$

Creditor Protection $(\xi)$ on Output, Credit and Spread.

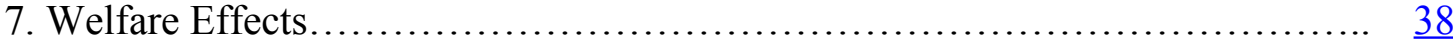

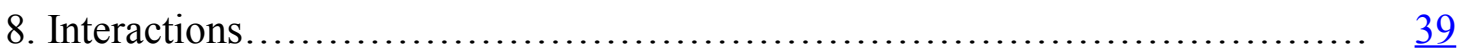

9. Equilibrium with Alternative Savings Instruments........................... $\quad \underline{\underline{39}}$

10. Equilibrium with a "Floor" on the Deposit Rate............................. $\underline{40}$

11. Sensitivity to the Deposit Supply Function................................ 40 


\section{Introduction}

Most countries have a formal bankruptcy procedure (hereinafter "bankruptcy technology") for dealing with corporate debt distress. ${ }^{1}$ Hart (1995) and others have suggested that a bankruptcy technology for private debt should meet the following three key principles to achieve the first best outcome: provide incentives for creditors to monitor debtors' actions (ex-ante efficiency), maximize the value of debtors' assets (ex-post efficiency), and preserve the absolute priority of claims (absolute priority rule or $\left.\mathrm{APR}^{2}\right){ }^{3}$

This paper analyzes the impact of deviations from Hart's metric on credit market equilibrium and capital accumulation through the lens of a simple dynamic general equilibrium model embedded with a stylized debt contracting problem. The bankruptcy technology is decribed by two exogenous parameters that proxy for two key features of bankruptcy resolution-the cost of resolving bankruptcy, which relates to Hart's ex-post efficiency, and the degree of creditor protection, which relates to the APR. The problem is analyzed in a contracting environment that embeds incentives for achieving ex-ante efficiency. The paper does not analyze the implications of bankruptcy technology in isolation. Instead, it recognizes from the start that an inefficient bankruptcy system may perversely interact with distortions in product and input markets thereby amplifying their negative macroeconomic effects. The paper focuses on nonfactor costs of running a business that in the real world would be typically identified with red tape and other deadweight losses to entrepreneurship. To keep matters simple, this third ingredient is also described by an exogenous parameter describing the cost of running a business or an investment project in the model.

The three problems analyzed in this paper-costly bankruptcy resolution, weak creditor protection, and deadweight losses to investment-are closely related to real world 'structural' distortions in financial and non-financial markets that are known to harm financial intermediation, productivity, and long-run growth. ${ }^{4}$ Implementation of structural reforms that reduce or eliminate these distortions is an integral part of the core recommendations of multilateral institutions like the IMF and the World Bank. In this context, policy makers have also urged the implementation of structural reforms to overcome the "mediocre" growth following the global financial crisis. ${ }^{5}$

A look at the data reveals two interesting facts. First, there is large cross-country variation in the the costs of running a business and resolving insolvency and in the degree of creditor protection (Table 1). For instance, the first row of the table shows that costs of starting a business (i.e., all official and legal fees) in countries at the top of the distribution is 10 times

\footnotetext{
${ }^{1}$ This paper does not cover issues pertaining consumer bankruptcy technology (e.g., Chatterjee et al. (2007)), or the resolution of sovereing debt distress. However, some of the principles and results discussed here could be applied to unincorporated business. Formal or statutory mechanisms for resolving sovereign debt distress have been proposed in the past but lacked support from the international comunity (e.g., Krueger (2002)). Gitlin and House (2015) provide an updated account of the ongoing debate on how to improve the resolution of sovereign debt crises.

${ }^{2}$ Under the APR, secured claims must be paid off before unsecured claims, and senior debt should be paid off before junior debt.

${ }^{3}$ This view of creditor rights does not necessarily apply in the context of sovereign. For instance, noneconomic considerations also play an important role in sovereign-to-sovereign debt contracts. See, for instance, IMF (2013), IMF (2014), IMF (2015), and IMF (2016)).

${ }^{4}$ See, for instance, Castro et al. (2004), Beck and Levine (2005), Japelli et al. (2005), Djankov et al. (2007), Dabla-Norris et al. (2013), as well as Christiansen et al. (2013) and their literature survey.

${ }^{5}$ See, for instance, http://www.imf.org/external/np/speeches/2015/040915.htm.
} 
larger than in countries at the bottom of the distribution. The other indicators shown in Table 1 also have large dispersion. Specific country examples further illustrate this pattern. For example, the cost to comply with all procedures to obtain a permanent electricity connection and supply in the Solomon Islands is over 100 times larger than in Australia; the cost of insolvency proceedings (i.e., judicial reorganization, liquidation or debt enforcement proceedings) in Venezuela is about 10 times larger than in Belgium; whreas secured creditors are 10 times more likelier to recoup their loans in United States than in Liberia.

Second, the data shows that income per capita and private credit/GDP are negatively correlated with the costs of running a business and resolving insolvency, and positively correlated with lending spreads; the correlations with creditor protection are the opposite, as expected (Figure 1). These unconditional correlations do not necessarily imply causality but are consistent with the evidence based on formal econometric analysis and country experiences. As discussed in Section 2, these findings suggest that constraints to entrepreneurship and financial intermediation do exert a significant negative impact on economic and financial development.

This paper focuses on the macro outcomes and hence will not explore the cross-country distribution of the costs of running a business and bankruptcy technologies. Specifically, it will look at the interaction between the three distortions identified above and its impact on the allocation of credit, borrowing costs and investment decisions. Conditional on reasonable parameter values and assumptions about preferences and technology, the simple model developed in this paper is able to reproduce the empirical regularities shown in Figure 1.

To put together the building blocks of the model, I follow Bernanke and Gertler (1989) and many others thereafter. I assume a two-period overlapping generations (OLG) structure, which helps account for agent heterogeneity while abstracting from complex repeated games. The model has two types of agents, savers (lenders) and investors (entrepreneurs) who differ with respect to preferences and access to savings instruments. The model also features different technologies for producing the consumption and capital goods. The former is produced by a standard Cobb-Douglas technology but the capital good is a stochastic function of investment projects. These have endogenous scale and are carried out by entrepreneurs.

I also assume a financial intermediary (bank) that allocates funds between savers and investors through a debt contract. Entrepreneurs have private information about the returns of their projects, while the bank can learn about the returns at a cost. Townsend (1979) and Gale and Hellwig (1985) have shown that a standard debt contract (SDC) is the optimal financial arrangement in this context. Under the SDC, the lender monitors the borrower's project when default occurs, the project is then liquidated and the bank receives as much as possible from the remaining assets to compensate for the monitoring cost, subject to the borrower's limited liability constraint.

In this contracting problem, I treat the cost of resolving bankruptcy and the lender's monitoring cost as the same, while noting that in the real world this cost could also encompass both direct (e.g., legal fees, court expenses) and indirect (e.g., loss of asset value while the case is in court) liquidation costs. In the model, the parameter describing the cost of resolving bankruptcy affects the net value of assets of a distressed project. The contract also incorporates a novel parameter describing how assets are distributed between stakeholders, and is intended to describe legal exemptions, deviations from the APR, and asset diversion by insiders. In the model, I treat this parameter as a measure of creditor protection. While this new feature does not overturn the optimality of the SDC, it weakens the bonding role of debt by making 
strategic default more likely. Hence, as in Longhofer (1997), I use the term "modified" SDC to refer to the contract with partial creditor protection. The third key ingredient describes nonfactor costs of running an investment project. It enters the model like a distortionary tax on entrepreneurial savings and the use of capital, thus affecting equilibrium outcomes by reducing entrepreneurial equity and increasing the effective price of capital.

To assess the positive and normative implications of the model, I start with a baseline calibration that roughly mimics the U.S. economy (benchmark). Next, I simulate the longrun impact of deviations from the benchmark on output per capita, credit market outcomes, and welfare. These simulations show the economic and welfare gains from reducing these distortions to levels that are comparable to those of the United States.

These are the main results of the paper. First, bringing to U.S. levels the costs of doing business in countries at the top quartile of the distribution (e.g., Cambodia, Côte d'Ivoire) could reduce their income gap relative to the U.S. by as much as 20 percent over the long run. Increasing creditor protection in countries at the bottom quartile of the distribution (e.g., Phillipines and Egypt) could also yield similar output gains. The gains from reducing bankruptcy costs to U.S. levels are lower but non-negligible, amounting to as much as 7 percent for countries like Ukraine and Venezuela. These reforms could also produce higher levels of financial intermediation and lower borrowing costs (Figure 6), and double-digit welfare gains (Figure 7 ). The latter are comparable to and even exceed the gains that only radical policy reforms would produce, for instance reducing to zero the capital income tax in the U.S.

These experiments measure the marginal effects of individual reforms and hence do not reveal the possibly larger gains from implementing several reforms at the same time. In fact, poor performers tend to do badly in most categories of the Doing Business Indicators and other similar measures of competitiveness. Rarely is a country a top performer in one dimension while scoring poorly in others. This suggests that reducing distortions that interact with each other could potentially amplify the payoffs.

The second contribution of this paper is to show that these interactions matter. They tend to amplify the individual effects on equilibrium outcomes, doubling or even tripling those effects depending on the size of individual distortions. Moreover, the interactions often work in a non-linear fashion.

To illustrate, large bankruptcy costs combined with even moderate levels of creditor protection may lead to disproportionately larger lending interest spreads (Figure 8). However, interactions may also work in unexpected ways. For instance, very low creditor protection combined with moderate-to-large bankruptcy costs may actually lead to lower lending spreads than when bankruptcy costs are small. This counterintuitive outcome reflects the direct and indirect (through the financial contract) effect of protection on spreads. Low levels of protection always reduce lending spreads through the direct effect. But they also raise the minimum return consistent with entrepreneurial solvency and bank break even condition. Since this minimum return is positively correlated with default in the model, it would put upward pressure on spreads. But when protection is sufficiently low, the direct impact dominates thereby reducing spreads. This hints that low spreads do not always signal strong fundamentals. They may actually reflect general equilibrum responses to severe distortions in financial markets. The result also highlights some of the identification challenges that empirical researchers and policy makers would face in practice when trying to disentangle the marginal effects of structural reforms.

Third, if savers have an alternative savings instrument (e.g., a risk-free assets abroad) and 
distortions become so severe as to reduce the return on bank deposits below the return on the alternative asset, the supply of credit would collapse and financial intermediation would come to a halt (Figure 9). In this case, investment would be financed by internal funds only and the economy would be trapped in an autarkic equilibrium. Imposing a floor on deposit rates $^{6}$ could mitigate the negative spillovers on financial intermediation but would not solve the underlying problems nor eliminate their large economic costs (Figure 10).

Finally, the impact of the distortions on output and financial intermediation is not always monotonic as common sense would suggest but could depend on the sensitivity of the loan supply to the interest rate. When the loan supply is upward-sloping as assumed in this paper, an improvement in the bankruptcy technology would shift up the demand for credit and increase the volume of credit in equilibrium, thereby unambiguously raising output and welfare. But if the loan supply happens to be downward-sloping (depositors have very high risk aversion) then the gains in terms of output (and welfare) become less obvious (Figure 11). Intuitively, an upward shift in loan demand would reduce credit in equilibrium as long as loan demand is more elastic than loan supply as implied by the baseline calibration of the model. Whether this situation is empirically relevant remains an open issue not explored in this paper.

There are five remaining sections. Section 2 discusses the relation of this paper with the literature. Section 3 presents the model and its theoretical predictions. Section 4 explains the model calibration. Section 5 provides numerical simulations and discusses the quantitative results. Section 6 concludes.

\section{Related Literature}

This paper relates to several strands of the literature. The model parameter measuring how assets are distributed between stakeholders is a proxy for the severity of limited contract enforceability. On a more general level, Cooley et al. (2003) find that low contract enforceability has significant general equilibrium effects. More specialized models have confirmed the key insights of Cooley et al. For instance, Azariadis and Chakraborty (1999) use an OLG growth model in which capital is also produced from bank loans, as in this paper, but focusing on agency costs as a constraint to capital accumulation and abstracting from the other distortions studied here. Antunes et al. (2010) explore the aggregate implications of intermediation costs using an one-sector growth model with infinite planning horizon and credit-constrained entrepreneurs. They find that reducing these costs not only generates sizeable welfare gains but also reduces consumption inequality.

Castro et al. (2004) also rely on a model of credit-constrained entrepreneurs to measure the impact of investor protection on growth. They use a two-period OLG model of capital accumulation in which entrepreneurs may conceal resources and outside investors are unable to enforce contracts perfectly. They find that the degree of creditor protection has two opposing effects on growth. Better protection improves risk sharing and raises the demand for capital at any given interest rate (demand effect). But higher demand for capital increases the interest rate and lowers entrepreneurial income and capital accumulation in equilibrium (supply effect). Because the supply effect is stronger in closed economies, improving investor protection would generate more growth benefits in countries with lower restrictions on capital flows. I also find

\footnotetext{
${ }^{6}$ To be effective, this would require some sort of capital controls in the case of small open economies.
} 
similar negative supply effect on capital accumulation when the bankruptcy technology is very inefficient and assuming a different (CSV) contracting framework.

As in Krasa et al. (2008), this paper shows that weak creditor protection is inefficient because it leads to strategic default and hence to unnecessary and costly liquidation of economically viable enterprises. While I implicitly assume that liquidation always occurs through a formal bankruptcy procedure, Krasa et al. study a setup where the financial intermediary chooses optimally whether to enforce the contract, that is, whether to request the services of a bankruptcy court. On the other hand, their analysis is conducted in a static partial equilibrium framework, whereas this paper embeds the contracting problem in a dynamic general equilibrium model. The authors also show that because the SDC minimizes the number of verification states and hence bankruptcy costs, it always dominates any other deterministic contract (not necessarily debt). This is also true for the modified SDC studied here.

Rodriguez-Delgado (2010) looks at the interaction between the cost of bankruptcy procedures and firm-level behavior using a model that combines endogenous default and the canonical analysis of firm dynamics. His model implies that very inefficient bankruptcy procedureswhere inefficiency is measured by the fraction of assets lost and not accruing to the lender during the bankruptcy process-imply to lower levels of borrowing by firms, constrain firm size and lead to significant output losses at the firm and aggregate levels. But since he does not disentangle the issue of creditor rights from bankruptcy cost (these are encapsulated into the same parameter) as I do in this paper, his model is unable to measure the marginal output costs of these two key features of bankruptcy procedures.

This paper also relates to and borrows insights from the corporate finance literature and case studies. On the theoretical side, Longhofer (1997) shows that APR violations lead to opportunistic default, exacerbate credit rationing and increase the interest rate; Bebchuck (2002) argues that APR violations induce borrowers to choose riskier projects as more risk is shifted to creditors in bad states; and Longhofer and Carlstrom (1995) show that APR violations increase bankruptcy costs, credit rationing and interest rates, and reduce the entrepreneur's commitment to the success of the project.

On the empirical front, Berkowitz and White (2004) study the effects of legal exemptions allowed by U.S. bankruptcy courts under Chapter 7 on small firms' access to credit in U.S. states. Using data for unincorporated business in all U.S. states, they find that small firms are more likely to face credit rationing and higher interest rates in states with unlimited homestead exemption. In 2005, Brazil reformed its 60-year old corporate bankruptcy law, including to better balance the rights of creditors and debtors. Under the old law, tax and wage claims had absolute priority but under the new law secured claims are second only to wage claims. The new law also attempts to speed up the resolution of bankruptcy. ${ }^{7}$ Based on firm-level data, Araujo et al. (2012) find that the new law has increased firms' borrowing capacity and reduced borrowing costs. Bergoeing et al. (2002) use a macro model and data for Chile and Mexico to compare the outcomes of reforms in these countries' bankruptcy and banking systems. The authors find that the earlier reform of bankruptcy procedures in Chile is key to explaining why Chile exited faster than Mexico from the crisis in the 1980s.

The literature has found that impediments to entrepreneurship in the form of costly and

\footnotetext{
${ }^{7}$ Under the old law, tax and wage claims had absolute priority, whereas under the new law secured claims are second only to wage claims. The new law also attempts to speed up the resolution of bankruptcy. See Araujo and Funchal (2005) for more details.
} 
unecessary business regulations and corruption are detrimental to business creation, productivity and growth. For instance, using data on European firms, Klappler et al. (2006) find that high costs of complying with bureaucratic requirements for incorporation harm the creation of new firms and slow down growth of existing firms. In the same vein, Kaplan et al. (2011) find that a program that reduced start-up regulatory costs in Mexican municipalities increased the rate of formal firm creation. Similar evidence comes from Brazil, where a program for simplifying bureaucracy and tax compliance for small businesses significantly reduced informality in the eligible sectors (Monteiro and Assuncao (2011)). Ciccone and Papaioannou (2007) find that countries with less time-consuming government procedures (i.e., red tape) to register new businesses experience more firm entry in industries benefiting from positive demand shocks and technology shifts.

Barseghyan (2008) estimates that entry costs also have powerful aggregate effects and help explain cross-country income differences. He finds that a half standard deviation increase in his measure of entry costs reduces total factor productivity and output per worker by 22 percent and 29 percent, respectively. Similarly, using data from the World Bank's Doing Business reports, Haidar (2012) estimates that each individual business regulatory reform as measured by this database increases per capita GDP growth by 0.15 percentage points on average. Divanbeigi and Ramalho (2015) also use the Doing Business database and estimate that improving business regulations from the bottom to the top quartile increases per capita income growth by about 0.8 percentage points. They also find that reforms that facilitate access to credit and insolvency resolution and improve investor protection are good for longrun growth. Finally, Dreher and Herzfeld (2005) find that constraints to entrepreneurship in the form of corruption has a significant negative impact on growth and GDP per capita.

To sump up, while the issues studied here are not novel, this paper offers new insights on key transmission channels, on the implications for long-run income levels and welfare, and on the potentially non-linear interactions between the distortions. I strived to keep the model as simple as possible yet rich enough to be able to assess meaningful policy implications. The paper is also an attempt to replicate the disperse findings of the literature with a single conceptional framework and minimum data requirements.

\section{Model}

\subsection{Overview}

This section presents a standard OLG model incorporating the following additional features: young and old generations have heterogeneous agents; consumption and capital goods are produced using different production technologies; and a stylized financial intermediary. I assume a closed economy with no government or money. Labor supply is inelastic and there is no decision for entry into entrepreneurial or financial activities. Because there is no aggregate uncertainty, economic outcomes are consistent with agents having perfect foresight at the macro level. Throughout the paper, I use lower-case letters for individual variables and capital letters for aggregate variables. To simplify notation, I will ignore the generation index.

Time, indexed by $t=0,1,2, \ldots$, is discrete and infinite. One time period is equivalent to 10 calendar years, which is a reasonable approximation for the duration of long-term investment projects. There are overlapping generations of agents whose planning horizon is two 
periods. I abstract from population growth and normalize the size of each generation to one. Agents are heterogeneous across cohorts and within cohorts. Individuals belonging to the same cohort differ in terms of preferences and access to technology. Each generation consists of an exogenous fraction $\eta$ of risk-neutral entrepreneurs and a fraction $1-\eta$ of risk-averse households. ${ }^{8}$

There are two goods, consumption and capital. The production of capital is carried out by entrepreneurs and is explained in detail below. The consumption good is produced by a representative firm using a standard Cobb-Douglas technology:

$$
Y_{t}=K_{t}^{\alpha}
$$

where $Y_{t}$ is output per worker, $K_{t}$ is capital per worker, and $\alpha \in(0,1)$ is the capital intensity. The consumption good-producing firm purchases capital at price $Q_{t}$ and hires labor at a wage rate $W_{t}$ in competitive factor markets. As in Azariadis and Chakraborty (1999), I abstract from sales of undepreciated capital between agents and assume that capital fully depreciates in the second period.

I assume that the costs of running a project affect the model outcomes through two channels. The first is the price of capital channel, whereby each unit of capital sold in the market incorporates a cost $\tau \in[0,1)$, with the effective cost of capital given by $(1+\tau) Q_{t}$. This is a simple way to reflect the fact that costly business regulations distort resource allocation, increase production costs and reduce economic efficiency at the aggregate level, in line with the evidence presented in Section 2. The parameter $\tau$ proxies for nonfactor costs of running a non-financial enterprise in the real world, such as the costs associated with red tape and other similar hurdles. This is a pure deadweight loss in the model and does not entail the provision of a public good as in the case of a traditional tax. The second channel is described in detailed below.

\subsection{Households}

Households have standard CRRA preferences, $u\left(c_{t}^{H}\right)=\left(c_{t}^{H}\right)^{1-\gamma} /(1-\gamma)$, where $c_{t}^{H}$ is individual consumption and $\gamma>0$ is the inverse of the intertemporal elasticity of substitution. The latter is a critical determinant of the supply of funds in an OLG economy. Savings are independent of interest rate if $\gamma=1$, increasing if $\gamma<1$, and decreasing if $\gamma>1$. When $\gamma \in(0,1]$, the elasticity of savings with respect to the interest rate is positive but small. This helps obtain a monotonically increasing policy function for the aggregate capital and a unique positive steady state. On the other hand, multiple equilibria may arise when $\gamma>1$. The baseline version of the model assumes $\gamma<1$, but I also provide numerical simulations considering different values for $\gamma$. While $\gamma>1$ may be a useful assumption for studying business cycle fluctuations and asset pricing issues, having $\gamma<1$ yields an upward-sloping loan supply function, ensures monotonicity and uniqueness of the capital policy function, and renders the long-run welfare analysis more meaningful.

In the first period of their economic lives, households are endowed with one unit of labor which they supply inelastically to the consumption good-producing firm. Households can

\footnotetext{
${ }^{8}$ Lenders (households) will be effectively risk-neutral for the purpose of the debt contract. Bernanke and Gertler (1989), among other, obtain this condition directly by assuming that lenders have risk-neutral preferences in the second period. Risk neutrality is required for the optimality of the debt contract.
} 
invest part of their income in bank deposits in period $t$ and receive a gross real return $R_{t+1}^{D}$ in $t+1$. The return on deposits is the price that clears the market for intermediated funds and will be pinned down in Subsection 3.6. In the second period, households receive the return on their savings, then consume and leave the economy (Figure 2).

A typical household solves the following savings problem, taking prices as given:

$$
s^{H}\left(R_{t+1}^{D}, W_{t}\right)=\arg \max _{s_{t}^{H}}\left\{u\left(W_{t}-s_{t}^{H}\right)+\beta u\left(R_{t+1}^{D} s_{t}^{H}\right)\right\},
$$

where $\beta$ is the time discount factor and $s^{H}\left(R_{t+1}^{D}, W_{t}\right)$ is the optimal savings function (i.e., the supply of deposits) which can be written as follows given the homogeneity of the utility function:

$$
s^{H}\left(R_{t+1}^{D}, W_{t}\right)=d_{t}=s^{H}\left(R_{t+1}^{D}\right) W_{t},
$$

where $s^{H}\left(R_{t+1}^{D}\right)=\beta^{\frac{1}{\gamma}}\left(R_{t+1}^{D}\right)^{\frac{1-\gamma}{\gamma}} /\left(1+\beta^{\frac{1}{\gamma}}\left(R_{t+1}^{D}\right)^{\frac{1-\gamma}{\gamma}}\right)$ is the marginal propensity to save.

To ensure that households have strictly positive consumption in a self-finance equilibrium and to reflect the fact that in the real world investors typically have alternative savings intruments, I also study an equilibrium where households have the option to invest in a riskfree asset which promises a fixed real return $R^{A}$. Think of this asset as an informal savings arrangement outside of the banking system, or a storage technology that does not contribute to capital accumulation (autarkic equilibrium).

\subsection{Entrepreneurs}

Young entrepreneurs are also endowed with one unit of labor which is supplied inelastically to the consumption good producer. Although I do not model the decision for entry into the capital good sector, I assume that the entrepreneur pays an upfront fee to operate the project, in line with the evidence presented in Section 2. To preserve simplicity, this cost is proportional to entrepreneurial income and is also equal to $\tau .{ }^{9}$ This is the second channel-net worth channel-through which distortionary business regulations enter the model. Thus the entrepreneurial net worth or disposable income is given by $(1-\tau) W_{t}$.

The savings decision by a young entrepreneur is the following:

$$
s^{E}\left(R_{t+1}^{E}, W_{t}\right)=\arg \max _{s_{t}^{E}}\left\{(1-\tau) W_{t}-s_{t}^{E}+\beta\left(R_{t+1}^{E} s_{t}^{E}\right)\right\}
$$

where I assume the same time discount factor. $R_{t+1}^{E}$ is the entrepreneurial expected rate of return to be derived below, and $s^{E}\left(R_{t+1}^{E}, W_{t}\right)$ is the optimal savings function:

$$
s^{E}\left(R_{t+1}^{E}, W_{t}\right)=s^{E}\left(R_{t+1}^{E}\right)(1-\tau) W_{t} .
$$

The function $s^{E}\left(R_{t+1}^{E}\right)$ is the entrepreneur's marginal propensity to save. $s^{E}\left(R_{t+1}^{E}\right)=0$ if $R_{t+1}^{E}<1 / \beta$ and $s^{E}\left(R_{t+1}^{E}\right)=1$ if $R_{t+1}^{E} \geq 1 / \beta$. When the expected return is too small entrepreneurs have no incentives to undertake any investment project, but will put their entire savings into the enterprise if the return is large enough (maximum equity participation). The latter is consistent with the evidence that entrepreneurs have a higher propensity to save than

\footnotetext{
${ }^{9}$ Assuming different marginal impact would not change the results of the paper but would add another layer of complexity.
} 
the rest of the population (Gentry and Hubbard (2004)). Therefore, the entrepreneur's net worth or contribution to the project is given by:

$$
s^{E}\left(R_{t+1}^{E}, W_{t}\right)=\left\{\begin{array}{cl}
0, & \text { if } R_{t+1}^{E}<1 / \beta \\
(1-\tau) W_{t}, & \text { if } R_{t+1}^{E} \geq 1 / \beta
\end{array} .\right.
$$

Henceforth, the paper will focus on equilibria with maximum equity participation.

I now turn to the technology for producing the capital good. Entrepreneurs have access to a private investment technology that uses the consumption good as input in period $t$ and returns the capital good in $t+1$. For simplicity, I assume the following linear investment technology, which together with an infinitely large number of projects, simplify aggregation and eliminate any entrepreneurial heterogeneity in equilibrium:

$$
k_{t+1}=x_{t+1} i_{t},
$$

where $i_{t}$ is the (endogenous) scale of the investment project, and $x_{t+1}$ is the stochastic return. This is i.i.d. across time and across entrepreneurs, drawn from a common distribution $F(x)$ with positive support, mean $\mu$ and variance $\sigma^{2}$. The corresponding density function $f(x)$ and hazard function $h(x)=f(x) /[1-F(x)]$ are twice continuously differentiable. To obtain a well defined solution for the loan contract below, I also assume that the hazard rate satisfies $\partial(x h(x)) / \partial x>0$, which is a rather weak restriction satisfied by many well-known distributions including the normal and its monotonic transformations like the lognormal (also see Bernanke et al. (1999)).

In the non-autarkic equilibrium, entrepreneurs finance their investment projects with net worth and loans from households through financial intermediaries. If next period's realized return is high enough, the entrepreneur repays the loan, consumes the net proceeds and leaves the economy. Otherwise, the entrepreneur declares bankruptcy and consumes whatever transfer is made by the bankruptcy court and then leaves the scene (Figure 2).

\subsection{Banks and Loan Contract}

Each entrepreneur implements at most one investment project which is funded by entrepreneurial net worth and (if needed) external funds. Direct transfers of the consumption good from households to entrepreneurs is too costly, hence resources are allocated more efficiently through competitive financial intermediaries or banks. These receive deposits from households and make one-period loans to entrepreneurs via debt contracts.

Banks take advantage of the law of large numbers to eliminate idiosyncratic entrepreneurial risk and guarantee a sure return to depositors. These depositors are effectively risk-neutral for the purposes of the financial contract because there is no aggregate uncertainty over the duration of the contract and because the law of large numbers ensures a risk-free deposit rate.

The outcome of the project is private information and verification by lenders is costly. If a bank wants to learn about $x_{t+1}$ it must pay a verification cost of $\kappa \in[0,1]$ per unit of capital verified. Thus, conditional on the realization of $x_{t+1}$, the total verification cost is $\kappa x_{t+1} i_{t}$. I assume deterministic verification because actual loan contracts resemble the contract considered in this paper and because Boyd and Smith (1994) have found that gains from stochastic contracts are quantitatively small. In equilibrium, this monitoring or verification cost will be incurred only when the project fails and hence will be interpreted as bankruptcy

CInternational Monetary Fund. Not for Redistribution 
costs. In practice, these would include the destruction of firm value due to negotiation and court delays, or more broadly the costs of closing a business.

Note that the nonfactor cost $\tau$ of running a project and the bankruptcy cost $\kappa$ describe different market frictions and have distinct implications for the equilibrium. While both are pure deadweight losses in the model, the first is equivalent to a distortive tax paid in every state of nature, whereas the latter is the marginal cost of transferring resources between agents in bankruptcy states. Also, in the model the cost of operating a business is partly borne by the entrepreneur and partly passed on to households through the higher price of capital, whereas the bankruptcy cost directly falls on banks.

When $W_{t}<i_{t}$, the entrepreneur must borrow $l_{t} \equiv i_{t}-(1-\tau) W_{t}$ consumption units from the bank, agreeing to repay $R_{t+1}^{K} l_{t}$ next period if the realized productivity $x_{t+1}$ is high enough, where $R_{t+1}^{K}$ is the gross lending rate in units of the capital good. Otherwise, the entrepreneur will declare bankruptcy, and the bank will verify and recover as much as possible from the project's return. The possibility of collateral is ruled out, although $(1-\tau) W_{t}$ can be thought as the collateralized portion of debt.

The degree of creditor protection is incorporated into the contracting problem through a function $\xi(x)$ that describes the amount of assets that the bank recovers in bankruptcy states. To avoid unlimited liability problems for the bank and entrepreneurs, I assume that $\xi(x) \geq \kappa$ and $x-\xi(x) \geq 0, \forall x$, respectively. If the bankruptcy system allows the bank to extract too much from entrepreneurs in bankruptcy states they would choose to invest with internal funds only or not invest at all. And if the bank is unable to cover at least the monitoring cost it would choose not to monitor ex-post, creating perverse incentives for borrowers. In short, credit markets would not function well if the bankruptcy system is biased either way. ${ }^{10}$

Townsend (1979) and Gale and Hellwig (1985) have shown that in an environment with costly state verification and deterministic monitoring, the optimal contract between riskneutral parties is a standard debt contract (SDC). Additionally, Longhofer (1997) has shown that debt is still optimal when a payment function resembling $\xi(x)$ is incorporated into the contracting problem ("modified" SDC). In fact, the SDC considered by Townsend and by Gale and Hellwig can be thought as a particular case (i.e., full protection) of the modified SDC.

Appendix A describes the properties of the modified SDC and derive are expected payoffs accruing to the entrepreneur and the bank, respectively,

$$
\begin{gathered}
R^{E}\left(\bar{x}_{t}\right)=\mu-\xi B\left(\bar{x}_{t}\right)-\xi \bar{x}_{t}\left(1-F\left(\bar{x}_{t}\right)\right), \\
R^{B}\left(\bar{x}_{t}\right)=(\xi-\kappa) B\left(\bar{x}_{t}\right)+\xi \bar{x}_{t}\left(1-F\left(\bar{x}_{t}\right)\right),
\end{gathered}
$$

where $\kappa B\left(\bar{x}_{t+1}\right) \equiv \kappa \int_{0}^{\bar{x}_{t}} x_{t+1} F\left(d x_{t+1}\right)$ is total expected bankruptcy cost, and $\bar{x}_{t}$ is the lowest project return under the modified SDC above which the entrepreneur is solvent, i.e., the solvency cutoff (also see Figure 3).

Using the Leibniz rule it is easy to show that $R^{E^{\prime}}(\bar{x})=-\xi[1-F(\bar{x})]<0$ and $R^{E^{\prime \prime}}(\bar{x})=$ $\xi f(\bar{x})>0$, thus $R^{E}\left(\bar{x}_{t}\right)$ is decreasing and convex in $\bar{x}$. Similarly, $R^{B^{\prime}}(\bar{x})=\xi[1-F(\bar{x})][1-$ $(\kappa / \xi) \bar{x} h(\bar{x})] \gtrless 0$ for $\bar{x} \lessgtr x^{*}$, where $x^{*}$ is such that $R^{B^{\prime}}\left(x^{*}\right)=0$. Also, $R^{B^{\prime \prime}}(\bar{x})=-R^{B^{\prime}}(\bar{x}) h(\bar{x})+$ $\kappa[1-F(\bar{x})] \partial(\bar{x} h(\bar{x})) / \partial \bar{x}<0$ for $\bar{x}<x^{*}$. Hence, $R^{B}(\bar{x})$ is strictly concave in the interval $\left[0, x^{*}\right]$

\footnotetext{
${ }^{10}$ This type of credit market distortions also affect the equilibrium outcome in Dubey et al. (2005). In their model, the debtor faces a utility punishment for defaulting and is better off not borrowing if the punishment is too harsh, whereas the lender chooses not to lend if the default penalty is too small.
} 
and reaches a global maximum at $x^{*}$ which is pinned down by the condition $x^{*} h\left(x^{*}\right)=\xi / \kappa$. Because the left-hand side of this condition is increasing in $x^{*}$, higher creditor protection and/or lower bankruptcy cost will increase the likelihood that incentive-compatibility and participation constraints for entrepreneurs and banks are met, thereby reducing the possibility of credit rationing or complete breakdown of the credit market.

The functions (5) and (6) are bounded above and below and the bounds depend on $(\kappa, \xi)$. It can be easily verified that $(1-\xi) \mu<R^{E}(\bar{x})<\mu$ and $0<R^{B}(\bar{x})<(\xi-\kappa) \mu$, as illustrated in Figure 4.

The lending rate and the loan size are the key decision variables in the contracting problem, but this can be more conveniently characterized by the solvency cutoff $\bar{x}_{t}$ and the scale of the project $i_{t}$. Given the limited liability constraints, the contingent payment rule in bankruptcy states, and prices $\left(Q_{t+1}, W_{t}\right)$, the optimal contract $\left(\bar{x}_{t}, i_{t}\right)$ maximizes the entrepreneurial expected income,

$$
\max _{\bar{x}_{t}, i_{t}} Q_{t+1} R^{E}\left(\bar{x}_{t}\right) i_{t}
$$

subject to the bank's break even condition,

$$
Q_{t+1} R^{B}\left(\bar{x}_{t}\right) i_{t} \geq R_{t+1}^{D}\left(i_{t}-(1-\tau) W_{t}\right)
$$

and the entrepreneur's participation constraint,

$$
Q_{t+1} R^{E}\left(\bar{x}_{t}\right) i_{t} \geq \frac{1}{\beta}(1-\tau) W_{t}
$$

The first constraint will always bind in equilibrium because financial intermediation is perfectly competitive and because I assume that entrepreneurs appropriate the economic profits generated by the contract, as in Carlstrom and Fuerst (1997). The second constraint requires a large enough entrepreneurial return for borrowing to take place.

Figure 4 illustrates that large $\xi$ reduces the capital income received by the entrepreneur, whereas large $\kappa$ or small $\xi$ reduces the income of the bank. In the extreme, very large $\kappa$ and/or very small $\xi$ would lead to violation of the bank's limited liability constraint and collapse of financial intermediation. Instead, in an environment where projects are countable or have fixed scale, credit rationing would arise (Longhofer (1997)). The problem above also indicates that, ceteris paribus, a large $\tau$ makes it more difficult to meet the bank's break even condition. Thus the model predicts that obstacles to entrepreneurship (large $\tau$ ), costly financial intermediation (large $\kappa$ ), and unbalanced mechanisms to resolve conflicts between debtors and creditors (small $\xi$ ) distort financing and investment decisions.

Given these distortions, the total capital income falls short of $\mu$ because part of it is destroyed or diverted away by the frictions assumed in the model:

$$
R^{E}\left(\bar{x}_{t}\right)+R^{B}\left(\bar{x}_{t}\right)=\mu-\kappa B\left(\bar{x}_{t}\right)
$$

This expression also illustrates the perverse interaction between the three distortions. For instance, weak protection will lead to an enlarged bankruptcy region (Figure 3) thereby increasing expected bankruptcy costs. The latter are further amplified by large $\kappa$. Equation (7) does not show a direct interaction between $\tau$ and the other two distortions but $\tau$ clearly destroys entrepreneurial income which will lead to lower capital output, thereby increasing 
the price of capital and leading to other perverse general equilibrium effects (also see Section 5).

The pair $\left(\bar{x}_{t}, i_{t}\right)$ satisfies the following first-order conditions:

$$
\begin{gathered}
Q_{t+1}\left[R^{B}\left(\bar{x}_{t}\right)+\left(1-\frac{\kappa}{\xi} \bar{x}_{t} h\left(\bar{x}_{t}\right)\right) R^{E}\left(\bar{x}_{t}\right)\right]=R_{t+1}^{D} \\
i_{t}=\psi_{t+1}(1-\tau) W_{t}
\end{gathered}
$$

where $\psi_{t+1}$ is the leverage ratio defined as:

$$
\psi_{t+1} \equiv \psi\left(R_{t+1}^{D}, Q_{t+1}\right)=\frac{R_{t+1}^{D}}{R_{t+1}^{D}-Q_{t+1} R^{B}\left(\bar{x}_{t}\right)} .
$$

Equation (8) pins down the solvency cutoff $\bar{x}_{t}$. If there is more than one $\bar{x}_{t}$ that satisfies (8), the optimal solution will be the smallest value because it would imply lower bankruptcy costs, that is, $\bar{x}_{t} \leq x_{t}^{*}$, where $x_{t}^{*}$ is the argument that maximizes $R^{B}\left(\bar{x}_{t}\right)$ and ensures that the term in parenthesis is nonnegative. Note that the debt contract will be the same for all entrepreneurs seeking external finance because $\bar{x}_{t}$ is independent of the loan value and the scale of the project. The model also implies that the default rate $F\left(\bar{x}_{t}\right)$ is independent of the project characteristics. Assuming a non-linear technology would overturn this result but complicate the contracting problem. Carlstrom and Fuerst (1997) point out that it is not clear whether this micro-level heterogeneity would have any relevant aggregate implications. Appendix B shows that $\bar{x}_{t}\left(R_{t+1}^{D}, Q_{t+1}\right)$ is decreasing in the deposit rate and increasing in the price of capital.

Equation (9) uniquely pins down the project size as a proportion of entrepreneurial disposable income, whereas (10) shows that corporate leverage depends on the same aggregate factors affecting $\bar{x}_{t}$. Appendix B also shows that $\psi_{t+1} \geq 1, \psi_{1, t+1}<0$ and $\psi_{2, t+1}>0$.

\subsection{Credit Market Outcomes and Supply of Capital}

The solution to the financial contract allows derivation of relevant rates of return and credit market indicators as functions of aggregate prices (all in units of the consumption good). From the entrepreneur's participation constraint and (9), the rate of return $R_{t+1}^{E}$ is given by:

$$
R_{t+1}^{E}=Q_{t+1} R^{E}\left(\bar{x}_{t}\right) \psi_{t+1}
$$

This is decreasing in the deposit rate and increasing in the price of capital if the leverage ratio is sufficiently large (see Appendix B). The equity premium $R_{t+1}^{E} / R_{t+1}^{D}$ will inherit the properties of (11). The gross lending rate $R_{t+1}^{L}$ is defined as the repayment to the bank in solvency states scaled by the loan size. Using (9) and rearranging terms give:

$$
R_{t+1}^{L} \equiv Q_{t+1} R_{t+1}^{K}=\frac{\xi \bar{x}_{t}}{R^{B}\left(\bar{x}_{t}\right)} R_{t+1}^{D}
$$

As expected, this satisfies $R_{t+1}^{L} \geq R_{t+1}^{D}$, hence the lending interest spread

$$
S_{t+1}^{L} \equiv \frac{R_{t+1}^{L}}{R_{t+1}^{D}}=\frac{\xi \bar{x}_{t}}{R^{B}\left(\bar{x}_{t}\right)}
$$


is larger than unity and increasing in the cutoff return $\bar{x}_{t}$. The lending rate is increasing in the price of capital, but the total effect of the deposit rate, including through $\bar{x}_{t}$, is ambiguous and will depend on the interest-rate elasticity of this cutoff value (Appendix B). Combining (9) and the loan size allows bank credit to be expressed as a function of the leverage ratio and entrepreneurial disposable income:

$$
l_{t}=\left(\psi_{t+1}-1\right)(1-\tau) W_{t}
$$

which will inherit the properties of the leverage ratio.

Finally, combining (4) and (7) gives the following supply of capital by a typical entrepreneur:

$$
k_{t+1}=\left[\mu-\kappa B\left(\bar{x}_{t}\right)\right] i_{t}
$$

This can be interpreted as the observed technology to produce the capital good using past investment as input. The term in square brackets is equivalent to the average productivity in the capital good sector and falls short of the average productivity $\mu$ as discussed above.

\subsection{Equilibrium with Financial Intermediation}

Under the usual regularity conditions (see below and Appendix C) and assuming reasonable parameter values (see Section 4) and strictly positive $K_{0}$, the model supports an equilibrium with financial intermediation. The aggregate capital stock is the only state variable in the model and fully characterizes all the decision rules. Given perfect competition in factor markets, input prices reflect the marginal product of capital and labor:

$$
\begin{gathered}
(1+\tau) Q_{t}=\alpha K_{t}^{\alpha-1}, \\
W_{t}=(1-\alpha) K_{t}^{\alpha} .
\end{gathered}
$$

Total savings and investment are obtained from aggregating (1) to (3) and (9) across agents:

$$
\begin{gathered}
S_{t}=\left[\eta(1-\tau)+(1-\eta) s^{H}\left(R_{t+1}^{D}\right)\right] W_{t}, \\
I_{t}=\eta \psi\left(R_{t+1}^{D}, Q_{t+1}\right)(1-\tau) W_{t} .
\end{gathered}
$$

Total consumption is the sum of the consumption of old entrepreneurs, and old and young households:

$$
C_{t}=\eta R_{t}^{E}(1-\tau) W_{t-1}+(1-\eta)\left[s^{H}\left(R_{t}^{D}\right) R_{t}^{D} W_{t-1}+\left(1-s^{H}\left(R_{t+1}^{D}\right)\right) W_{t}\right] .
$$

Aggregating (15) and combining with (17)-(18) give the law of motion for the aggregate capital stock:

$$
K_{t+1}=\left[\mu-\kappa B\left(\bar{x}_{t}\right)\right]\left[\eta(1-\tau)+(1-\eta) s^{H}\left(R_{t+1}^{D}\right)\right](1-\alpha) K_{t}^{\alpha} .
$$

The remaining equilibrium condition is the market clearing in the loan market. Aggregating (14) gives the total demand for loans:

$$
L_{t}=\eta\left(\psi\left(R_{t+1}^{D}, Q_{t+1}\right)-1\right)(1-\tau) W_{t}
$$


whereas household savings (deposits) determine the loan supply:

$$
D_{t}=(1-\eta) s^{H}\left(R_{t+1}^{D}\right) W_{t} .
$$

These two conditions pin down the equilibrium deposit rate:

$$
\frac{s^{H}\left(R_{t+1}^{D}\right)}{\psi\left(R_{t+1}^{D}, Q_{t+1}\right)-1}=\frac{\eta(1-\tau)}{1-\eta}
$$

The loan demand is unambiguosly decreasing in the deposit rate (see Appendix $\mathrm{C}$ ), whereas the loan supply is increasing in the deposit rate if $\gamma<1$, decreasing if $\gamma>1$, and independent

if $\gamma=1$ in which case $R_{t+1}^{D}=1 / \beta$. The first panel of Figure 5 illustrates the equilibrium with upward-sloping deposit supply (baseline). The middle panel shows the second case, i.e., downward-sloping deposit supply, and assuming that loan demand is more elastic than loan supply. The the last panel illustrates the third possibility, i.e., perfectly inelastic deposity supply.

Using equations (8) and (10) it is easy to express the leverage ratio as a function of the deposit rate/price of capital ratio. Using this result and dividing (22) by output gives a convenient expression for credit-to-GDP ratio:

$$
L_{t+1}^{Y}=\eta(1-\alpha)(1-\tau)\left(\psi\left(\frac{R_{t+1}^{D}}{Q_{t+1}}\right)-1\right) .
$$

This inherits the all the properties of the leverage ratio. Also note that the costs of running a project $\tau$ has a direct negative impact on financial intermediation.

\subsection{Self-Finance Equilibrium}

A self-finance equilibrium arises in the following situations: the expected deposit rate is lower than the return on the storage technology $\left(R_{t+1}^{D}<R^{A}\right)$, or the bank's limited liability constraint is violated; and the entrepreneurial expected return under the loan contract is lower than the time discount factor $\left(R_{t+1}^{E}<1 / \beta\right)$ or the cost of running a project is too large. These two cases illustrate the collapse of credit supply and credit demand, respectively.

In the self-finance equilibrium, aggregate savings are no longer equal to productive investment. The latter is fully determined by entrepreneurial equity:

$$
I_{t}=\eta(1-\tau) W_{t}
$$

with the expected rate of return on entrepreneurial equity becoming a linear function of the price of capital:

$$
R_{t+1}^{E}=\mu Q_{t+1}
$$

The expected supply of capital by a typical entrepreneur, i.e. the analogue of (15), is given by $k_{t+1}=\mu i_{t}$. Hence, the aggregate stock of capital evolves according to:

$$
K_{t+1}=\eta \mu(1-\tau)(1-\alpha) K_{t}^{\alpha}
$$

It is clear from (26) and (28) that higher costs of doing business hurt investment and capital accumulation. This distortive effect is stronger in autarky than in the equilibrium 
with financial intermediation. It is easy to check that the first-order effect of $\tau$ on the capitalto-output ratio $\left(K_{t+1} / Y_{t}\right)$ in autarky, $-\eta \mu(1-\alpha)$, is larger (in absolute value) than that under financial intermediation, $-\eta\left[\mu-\kappa B\left(\bar{x}_{t}\right)\right](1-\alpha)$.

Aggregate consumption is analogous to (20), but with household savings being determined by the constant return $R^{A}$.

\subsection{Steady State and Welfare}

The model is isomorphic to a standard OLG model with either a labor income tax or a capital adjustment cost, reflected in the first square brackets of (21), and also in equation (28).

The three distortions studied in this paper, especially bankruptcy costs and partial creditor protection, complicate the dynamics of the capital stock in two aspects. First, the shape and dynamics of (21) depend not only on the usual interaction between preferences and technology, but also on the interaction between these two and the distortions. Second, information about the future capital is conveyed not only by the savings rate via the price of capital and the interest rate (second square brackets) but also by the financial contract (encapsulated in the solvency cutoff $\bar{x}_{t}$ ).

To have a better sense of how the steady state capital is impacted in the equilibrium with financial intermediation, assume $\log$ utility and solve (24) for $\bar{x}_{t}$ as a function of $Q$ and $R^{D}$ :

$$
\bar{x}=R^{B^{-1}}\left(\frac{(1-\eta) \beta}{\eta(1-\tau)+(1-\tau \eta) \beta} \frac{R^{D}}{Q}\right) .
$$

Next, substitute this into (21) to obtain:

$$
K=\left[\mu-\kappa B\left(R^{B^{-1}}\right)\right]\left(\frac{(1-\tau) \eta+(1-\tau \eta) \beta}{1+\beta}\right)(1-\alpha) K^{\alpha} .
$$

This shows that the distortions make the capital correspondence highly non-linear and possibly non-monotonic. As a result, (21) may converge to multiple steady states depending on the initial condition. Appendix $\mathrm{C}$ discusses the necessary conditions for the existence of at least one positive and locally stable steady state in the general case.

When distortions (especially bankruptcy costs) are negligible, the financial contract no longer affects capital accumulation. To see this, assume that payoffs are proportional to each party's contribution to the project, in which case payments received by the entrepreneur and the bank would be $Q \mu(W / I) I$ and $Q \mu(1-W / I) I$, respectively. Rates of return would be fully equalized, $R^{D}=R^{E}=R^{L}=\mu Q$, with lending spread and equity premium converging to unity. In this scenario, the scale of the project becomes indeterminate and total investment will be pinned down in general equilibrium by aggregate savings. The indeterminacy of the corporate financing structure (i.e., leverage ratio) is a manifestation of the Modigliani-Miller theorem. The law of motion of capital (21) would take the following form:

$$
K_{t+1}=J\left(Q_{t+1}\right)(1-\alpha) K_{t}^{\alpha},
$$

where

$$
J\left(Q_{t+1}\right) \equiv \mu \frac{\eta+\beta^{\frac{1}{\gamma}}\left(\mu Q_{t+1}\right)^{\frac{1-\gamma}{\gamma}}}{1+\beta^{\frac{1}{\gamma}}\left(\mu Q_{t+1}\right)^{\frac{1-\gamma}{\gamma}}}
$$


In the special case of logarithmic preferences, savings would become independent of the deposit rate, the function $J\left(Q_{t+1}\right)$ would only depend on model parameters, and the economy will reach a unique, globally stable and positive steady state (Galor and Ryder (1989)):

$$
K=\left(\mu \frac{\eta+\beta}{1+\beta}(1-\alpha)\right)^{\frac{1}{1-\alpha}} .
$$

This equation actually describes the first-best allocation that is achieved when all costs are zero and the deposit supply is vertical.

In the self-finance equilibrium, it is straightforward to check that

$$
K=[\eta \mu(1-\tau)(1-\alpha)]^{\frac{1}{1-\alpha}},
$$

and

$$
Q=\frac{\alpha}{\eta \mu(1-\alpha)\left(1-\tau^{2}\right)} .
$$

Thus $\tau$ destroys capital accumulation and increases the price of capital, exactly like a distortionary tax would do. Under the baseline calibration, the rate of return in (27) will always exceed $1 / \beta$. Therefore, the entrepreneur will always fund the project with maximum equity participation, thereby ensuring a non-trivial steady state even when financial intermediation collapses.

For the purposes of welfare analysis, I assume a separately additive welfare function that aggregates the preferences of entrepreneurs and households using population size as weight. Furthermore, I ignore any transition dynamics and focus on the long-run implications. The discounted present value of social welfare can be expressed as follows:

$$
\text { Welfare }=\frac{1}{1-\beta}\left[\eta u^{E}\left(R^{E}, W\right)+(1-\eta) u^{H}\left(R^{D}, W\right)\right] .
$$

The first term inside square brackets is the entrepreneur's value function weigthed by the fraction of entrepreneurs in the population and the second terms is households' value function weighted by their population size. In the simulations presented in Section 5 , welfare gains are measured in terms of consumption equivalents.

\section{Functional Forms and Parameters}

The baseline version of the model is calibrated to the U.S. economy, which I treat as benchmark. The United States ranked the 7th best economy in the 2017 Doing Bussiness and was positioned in the top 5 th percentile of the distribution based on all indicators (Doing Business (2017)).

The capital income share $\alpha$ is set to 0.4 and $\eta$ to 0.15 , roughly the fraction of entrepreneurs in the U.S. population (Singer et al (2015)). The baseline calibration assumes $\gamma=0.5$ so that the loan supply schedule is upward sloping. Using microdata from household income and wealth survey, (Chiappori and Paiella (2011) report a median risk aversion coefficient of about 1.7, close to values typically used to calibrate business cycle models. Appendix D and Figure 5 show the implications of assuming logarithmic preferences and $\gamma=2$. The discount 
factor $\beta$ is chosen so that the deposit rate in the model roughly matches the real return (in decennial terms) on the 6-month certificate of deposit in U.S. since the World War II.

I assume that $F(x)$ is lognormal with parameters $\mu_{x}$ and $\sigma_{x}$. Thus $\ln (x) \sim N\left(\mu_{x}, \sigma_{x}^{2}\right)$, where $\mu_{x}$ and $\sigma_{x}^{2}$ are related to the mean and variance of $x$ through the standard properties of the lognormal distribution:

$$
\begin{aligned}
& \mu_{x}=2 \ln (\mu)-\frac{1}{2} \ln \left(\mu^{2}+\sigma^{2}\right), \\
& \sigma_{x}^{2}=-2 \ln (\mu)+\ln \left(\mu^{2}+\sigma^{2}\right) .
\end{aligned}
$$

Given these assumptions, the expected capital income accruing to the bank and the entrepreneur will take these simple functional forms:

$$
\begin{aligned}
& R^{E}(\bar{x})=(1-\tau)[\mu(1-\xi) B(\bar{z})-\xi \bar{x}(1-\Phi(\bar{z}))], \\
& R^{B}(\bar{x})=(1-\tau)[\mu(\xi-\kappa) B(\bar{z})+\xi \bar{x}(1-\Phi(\bar{z}))],
\end{aligned}
$$

where $\kappa B(\bar{z})=\kappa \Phi\left(\bar{z}-\sigma_{x}\right)$ is the bankruptcy cost, $\Phi($.$) is the c.d.f. of the standard normal$ and $\bar{z} \equiv\left(\ln (\bar{x})-\mu_{x}\right) / \sigma_{x}$.

The average productivity $\mu$ is chosen so that the entrepreneurial rate of return in (11) roughly matches the real return on the S\&P 500 after World War II. ${ }^{11}$ The volatility parameter $\sigma$ is chosen to match the business bankruptcy rate over a 10-year period. Available estimates of failure rates over this time span vary quite a lot. For instance, the annualized values used by Carlstrom and Fuerst (1997) and Bernanke et al. (1999) would imply a decennial bankruptcy rate around 30-40 percent. Phillips and Kirchhoff (1989) estimate that 60 percent of new firms do not survive 6 years or more, roughly consistent with survival rates reported by the BLS. However, Headd (2003) reminds that only one third of the closures are under circumstances that entrepreneurs consider unsuccessful, which would bring the actual failure rate implied by the BLS data and alike to about 20 percent. In fact, Phillips and Kirchhoff cite that the "involuntary" failure rate implied by data from Dun and Bradstreet-excluding voluntary reasons such as the owners' decision to retire-is about 25 percent. My choice of $\sigma$ implies a bankruptcy rate around 35 percent, in the range of the available estimates. Given $\mu$ and $\sigma$, the above equations pin down $\mu_{x}$ and $\sigma_{x}$.

Matching the triple $(\tau, \kappa, \xi)$ to observable counterparts is not straightforward, so I use the Doing Business Indicators listed in Table 1 to derive proxies for these parameters. First, I eliminate the extreme observations (top and bottom 2 percentiles) from the various indicators measuring the cost of running a business, then measure them all relative to the business's value, and finally normalize the combined index to $[0,1]$. The cost of resolving insolvency and the recovery rate do not require any normalization. These adjusted values-shown in Table 1 and Figure 1-are the empirical counterparts of $(\tau, \kappa, \xi)$ in the model. Based on this data, I obtain these rounded figures $(.1, .2,1)$ for the U.S. The size of $\tau$ looks reasonable given the relative position of the United States in the Doing Business Indicators; the value of $\kappa$ is between that of Bernanke et al. (1999) and Carlstrom and Fuerst (1997); and the value of $\xi$ is consistent with strong creditor protection observed in the United States.

\footnotetext{
${ }^{11}$ This is close to the average return on assets of publicly traded firms across the world in the 1990s (Claessens et al. (2000)). Evidence also suggests that average returns to private equity in the U.S. are approximately equal to S\&P 500 (e.g, Moskowitz (2002) and Kaplan and Schoar (2005)).
} 
The baseline calibration generates reasonable model statistics. For instance, the lending spread implied by (13) roughly matches the spread between the prime lending rate and the return on 6-month certificate of deposit. It also generates a leverage ratio around 3.5, the same order of magnitude of the data; an entrepreneurial share of capital income equal to 33 percent, around the value calibrated by Carlstrom and Fuerst (1997); and a gross equity premium also commensurate with the data. The baseline calibration also ensures that limited liability and participation constraints are all satisfied. Table 2 summarizes the baseline parameter values.

\section{Results}

In this section, I evaluate the quantitative properties and welfare implications of the model. The analysis ignores transition dynamics and focuses on steady state outcomes. The first part shows the marginal effects of $(\tau, \kappa, \xi)$ on the variables of interest, under the baseline value for the intertemporal elasticity of substitution, and assuming that depositors do not resort to the storage technology. The second part discusses welfare implications. The third part looks at the impact due to interactions. The fourth discusses equilibria with alternative savings instruments and interest rate controls. The last part analyzes implications from alternative values for the intertemporal elasticity of substitution.

\subsection{Marginal Effects}

Figure 6 shows the long-run effects of changes in each distortion (each column) on three key variables of interest-output per capita, credit-to-output, and lending interest spread, while keeping the others distortions at their baseline values. This figure shows that the model can replicate all the empirical regularities presented in Figure 1. Each path shown in the figure can be read as the outcome of policies that reduce the size of each distortion to U.S. levels.

The first column shows the net impact of the cost of running a project $(\tau)$ through the cost of capital and net worth channels. The impact of both channels on production factors and income resembles that of a non-lump sum tax on capital and labor. Therefore, reducing the cost of doing business would unambiguously increase capital accumulation and output per capita in the long run. The first panel of Figure 6 shows that output gains are very large, up to 30 percent, depending on a country's position relative to the U.S. However, the impact of each channel on credit and lending spreads differ markedly. On one hand, large costs of doing business would reduce the demand for capital, leading to lower demand for credit and lower lending spreads. On the other hand, large $\tau$ reduces entrepreneurial equity and would require higher external funds (i.e., leverage) for a given investment project. In turn, this would lead to more credit and larger lending spreads. Thus, the cost of capital channel implies lower financial intermediation and spreads, whereas the net worth channel implies the opposite. Under the baseline calibration, the first channel dominates the impact on the volume of credit, while the second dominates the impact on the price of credit, thereby unambiguously leading to lower credit and larger spreads in general equilibrium. Figure 6 would suggest that bringing to U.S. levels the costs of doing business in countries like Cambodia or Cote d'Ivoire, which are ranked at the top quartile of the distribution for bankruptcy costs $(\tau$ around $.6-.8)$ could reduce their income gap relative to the U.S. by as much as 20 percent over the long run, a large gain by any metric. 
The second column of Figure 6 shows the impact of reducing the cost of bankruptcy resolution. Higher bankruptcy costs make the bank payoff function flatter (Figure 4). Under the optimal contract, the solvency cutoff $\bar{x}$ would increase thus raising the default rate and borrowing costs. The resulting destruction of economic value would unambiguously lead to lower levels of investment and output. The model predicts that countries like Ukraine and Venezuela ( $\kappa$ close to one) could enjoy an increase in their income per capita by as much as 8 percent in the long run if they managed to bring their bankruptcy costs close to U.S. levels. They would also achieve some improvement, though more modest than in the previous case, in their financial development indicators.

Turning to the issue of creditor protection, the last column of Figure 6 shows that improving $\xi$ also benefits growth and financial intermediation. Higher protection reduces strategic default thereby making the bank payoff function steeper (Figure 4). As a result, the optimal contract will reduce the solvency cutoff $\bar{x}$, economize on monitoring costs and increase the expected capital output. Even though entrepreneurs receive relatively less from the bankruptcy court each time they fail, they go bankrupt less often and hence will choose to invest more and demand more credit. This will boost returns to depositors and the price of capital, leading to higher corporate leverage, while keeping lending spreads at relatively low levels. The model predicts possible double-digit output gains from increasing creditor protection in countries like the Phillipines and Egypt that are at the bottom quartile of the distribution for creditor protection ( $\xi$ around $.2-.3$ ).

Figure 6 also reveals that the impact of each distortion on output and credit is roughly linear but the responses of lending spreads are highly non-linear, a feature that may have been overlooked by the literature. The steeper response of spreads as $\tau$ approaches 1 reflects the workings of the net worth channel. The demand for bank lending becomes disproportionately large as an increasing fraction of entrepreneurial income is diverted to unproductive use. Consequently, the optimal response of the bank is to sharply increase the solvency cutoff $\bar{x}$ and hence lending spread (equation (13)). The reaction of spreads to $\kappa$ is somewhat the opposite. As resolution of insolvency becomes too costly, the bank will try to reduce the solvency cutoff, hence the default rate, as much as possible. For very large values of $\kappa$, the optimal response of the bank is strong enough to engineer a modest reduction in the spreads relative. Thus the spread displays a somewhat inverted U-shaped reaction to bankruptcy costs.

The figure shows that the response of spreads to $\xi$ is even more interesting. It clearly has an inverted U-shape and peaks when creditor protection is around .5. This non-monotonic behavior is the result of two forces, the direct effect of $\xi$ and the indirect effect through $\bar{x}$. Low levels of creditor protection require a higher solvency cutoff to meet the bank's break even condition. When protection falls below .5 its direct impact on spreads (equation (13)) dominates the indirect effect and spreads fall below the peak. But the indirect effect remains strong enough to keep spreads above the level under full protection. ${ }^{12}$ When protection is increased beyond .5 , the bank is able to reduce $\bar{x}$ without violating the break even condition, while simultaneously reducing expected bankruptcy costs. In this case, the indirect effect offsets the direct impact of $\xi$, bringing spreads down significantly. It is worth noting that higher creditor protection is associated with lower deadweight losses from firm liquidation

\footnotetext{
${ }^{12}$ Creditor protection below .2 typically violates the bank's limited liability constraint in the baseline calibration.
} 
thus improving the overall efficiency of the bankruptcy technology.

\subsection{Welfare Implications}

Reforms that improve bankruptcy technology and reduce the costs of doing business may yield significant welfare gains too. Figure 7 shows that the long-run welfare gains under the baseline calibration could reach double-digits. For instance, if Cambodia and Côte d'Tvoire were to reduce the costs of doing business to U.S. levels they would enjoy a steady-state welfare gain equivalent to a consumption increase of about 20 percent. Similar gains would accrue to countries like the Phillipines and Egypt if they improved creditor protection. Reducing bankruptcy costs would also yield significant welfare gains, as much as 10 percent of long-run consumption for countries like Ukraine and Venezuela.

These estimates are substantially larger than those typically found in the literature, perhaps by a order of magnitude, including because some of the available estimates focus on very specific channels or on average outcomes. For instance, Antunes et al. (2010) find that the gain from reducing financial intermediation costs could amount to 2 percent of consumption. Souza-Sobrinho (2010) finds similar gain from eliminating distortive cross-subsidies in the Brazilian loan market. While the estimates from the literature typically incorporate potential consumptions losses during the transition period, their long-run counterparts would remain modest compared to those show in Figure 7.

The estimates in this paper are more comparable to those from more radical policy changes. For instance, reducing to zero the capital income taxation in the U.S. would amount to $7.5-15$ percent of annual consumption in the long-run, abstracting from consumption losses during the transition (Lucas (2003)). In the same vein, the long-run welfare gain in consumption equivalents to French households would be 20 percent if France adopted the American tax system (Prescott (2002)). Furthermore, Rodriguez-Delgado (2010) simulates that aggregate output loss could amount to as much as 40 percent in the extreme case where lenders are unable to seize any assets in liquidation. The output cost is less related to inefficient liquidation and more to the fact that potentially viable projects are not undertaken, i.e., to missing firms.

While one not need to take the quantitative predictions of the model at face value, its qualitative implications are very clear: obstacles to entrepreneurship and financial intermediation are a major impediment to improving living standards in developing countries. As the distortions studied in this paper are often created and perpetuated by poorly designed policies and institutions, the predictions also help explain the slow speed of convergence of a large number of countries.

\subsection{Perverse Interactions}

The previous simulations were based on individual policy changes, abstracting from potential amplifying or dampening effects arising from simultaneous changes. In this section, I assess the net effect of policies that tackle more than one distortion at a time. Figure 8 presents the results for the same three variable of interest and based on deviations from the benchmark as before. Because changing more than one parameter at a time reduces the set of equilibria with financial intermediation, I constrain each parameter to a narrower range, namely $[.1, .5]$ for $\tau,[.2, .6]$ for $\kappa$, and $[.6,1]$ for $\xi$. Each panel in the figure shows three lines. The solid line is the baseline studied in the previous section, i.e., it describes the changes in only one 
parameter while keeping the others at their baseline values. The dashed line includes a shift in the second parameter while keeping the third at its baseline value. Finally, the dotted line incorporates a shift in the second and third parameters. To keep things in perspective, each parameter shifts to a point in the middle of each parameter's range, that is, .3 for $\tau, .4$ for $\kappa$, and .8 for $\xi$.

The figure does not reveal any significant amplifying or dampening effect for ouptut and credit, as illustrated by the parallel shifts in the curves. But this exercise is still useful because it shows the combined effect of the three distortions and also allow to decompose their individual effects. For instance, the income gap of a country that resembles the U.S. in all aspects except for the lower creditor protection (say .6) would be 10 percent. But if in addition its costs of doing business are three times larger than in the U.S. and its bankrtupcy costs are twice as large in the U.S. then its income gap would double to 20 percent (top right panel). This simple exercise suggests that to fully reap the benefits of reforms, countries with poor performance along the three dimensions should address all the distortions simultaneously.

Figure 8 also shows that the combined impact of the three distortions on lending spreads is far from being trivial. First, the interaction between the cost of doing business and bankruptcy cost does not seem to matter a lot (bottom left and bottom middle panels). This reflects the fact that even large changes in bankruptcy costs have modest impact on lending spreads (see Figure 6). However, the interaction between weak creditor protection and the other two distortions leads to non-linear and often unexpected effects on spreads. For instance, the combination of weak creditor protection and rising bankruptcy costs may actually reduce lending spreads if protection is already sufficiently low (dotted line in bottom right panel). As discussed in the previous section, this seemingly counterintuitive result reflects the two opposing forces under the loan contract, with the direct impact of weakening protection dominating the indirect effect through the solvency cutoff $\bar{x}$.

In a nutshell, low spreads do not always signal strong fundamentals but may actually reflect general equilibrum reactions to severe distortions in output and financial markets. The simulation also highlights some of the identification challenges that empirical researchers and policy makers would face in practice when trying to disentangle the marginal impact of individual distortions on the financial sector.

\subsection{Bankruptcy Technology and Capital Flight}

So far the baseline simulations implicitly assumed that households would always invest their savings in bank deposits even when distortions drive the gross deposit rate to very low levels, say below 1. I now relax this assumption and allow depositors to invest their savings in an alternative savings vehicle which promises a gross fixed return $R^{A}=1$. One can think of this asset as a storage technology that does not contribute to capital accumulation, or informal savings arrangements outside the banking system, or even the interest rate prevailing abroad. Whenever banks are unable to match $R^{A}$ or are forced to offer a lower deposit rate, households will invest their entire savings in the storage technology and investment projects will be funded by entrepreneurial net worth only. With this assumption, this section analyzes the impact of the bankruptcy technology (i.e., creditor protection and monitoring cost) on equilibrium outcomes.

Figure 9 shows the long-run effects on output, credit and lending spreads for different values for the bankruptcy cost and creditor protection. Under the baseline calibration, depositors 
decide to switch to the alternative savings instrument whenever bankruptcy costs or creditor protection is around .7. For values of bankruptcy cost (creditor protection) larger (lower) than .7 the supply of credit collapses and the economy switches to the self-finance equilibrium (equations (28) and (33)).

The self-finance equilibrium is akin to a situation where policies or market distortions depress the real return on savings, hurting financial development and growth (e.g., Levine (2005)). Souza-Sobrinho (2010) and others have shown that policies that distort loan pricing in the aggregate or across borrowers (e.g., directed lending practices) are detrimental to financial intermediation. It also echoes the experience of many developing countries with weak rule of law and poor governance where it is very costly to enforce contracts and where resources are often diverted from the formal economy to informal (often illegal) businesses or simply channeled abroad ("capital flight"). The latter coud have a particularly devastating impact on financial development and growth when intertwined with corrupt practices. ${ }^{13}$

The basic conclusion would also hold in a small open economy facing the rate of return $R^{A}$ and subject to the same distortions studied in this paper. One difference is that domestic capital could be further reduced if $R^{A}$ also exceeds the entrepreneurial rate of return. Facing such a severe circumstance, it is possible that policy makers would be more compelled to align the domestic bankruptcy technology to the best international practices.

What if households cannot switch to other savings instruments (e.g., because of large switching costs) and are forced to accept $R^{A}$ from banks? This scenario-equivalent to imposing a floor on the deposit rate-could sustain an equilibrium with financial intermediation entailing lower output and welfare losses relative to the cases depicted in Figures 6 and 9. However, the price control would interact with the bankruptcy technology in perverse ways, amplifying the negative effects on financial intermediation. Figure 10 shows that large bankruptcy costs (low creditor protection) would reduce credit by up to 10 percent (20 percent), or five times more than (twice as much as) the baseline case shown in Figure 6. Needless to say, improving the bankruptcy technology would be the appropriate course of action for boosting financial developing in this case.

The very large output losses implied by the autarkic equilibrium and its resonance with the situation of many developing countries also call for broad reforms, in particular strenghtening the rule of law and governance. These would provide the right incentives for investors and public decision makers and would potentially lead to better macroeconomic outcomes.

\section{Conclusion}

Obstacles to entrepreneurship and financial intermediation distort capital accumulation, worsen credit market outcomes and reduce welfare in the long run. These negative effects may be amplified when those obstacles interact with each other in perverse ways. The main message of this paper is that reforms that simultaneously reduce the costs of doing business and improve the technology for resolving insolvency would substantially increase economic well being in the long-run. The numerical simulations suggest that even relatively small improvements in these areas may yield significant economic gains.

\footnotetext{
${ }^{13}$ For a recent discussion on the impact of corruption on growth see, for instance, the G20 issues paper on the topic: https://www.oecd.org/g20/topics/anti-corruption/Issue-Paper-Corruption-and-Economic-Growth.pdf.
} 
In the model, higher creditor protection increases the overall efficiency of the bankruptcy technology and unambiguously leads to output gains because it reduces strategic default and costly liquidation. Departing from this paper and the large literature discussed in Section 2, Acharya and Subramanian (2009) argue (but without providing a full-fledged model) that a debtor-friendly bankruptcy code could lead to higher risk taking, innovation, and firm leverage relative to a creditor-friendly code. But this argument focuses on the entrepreneurs' perspective (i.e., loan demand), seems to overlook creditors' incentives (supply side), and it is not obvious that it holds in general equilibrium. Furthermore, while the hypothesis finds some support in a selected sample of advanced and emerging economies, it is also unlikely to reflect the reality of most low-income countries where debtor-creditor relationships are more prone to moral hazard, property rights are generally weaker, and firms tend to innovate less in the first place.

Which specific reforms could be considered by countries facing the obstacles studied in this paper? Better legal rules for resolving corporate distress, procedures to facilitate pledge and recovery of collateral, policies to expedite courts proceedings, regulation that promotes bank competition, better enforcement of contracts, one-stop investment windows, tougher rules against corruption, just to name a few. To the extent possible, bankruptcy codes should balance the rights of debtors and creditors as excessive bias in either direction could harm financial intermediation and growth. To maximize payoff, these reforms should follow the best international practices and be inspired by what has worked well in other countries.

Compared to production technologies, frameworks for promoting a business-friendly environment and efficient resolution of disputes are probably harder to transfer across countries, including because they depend on country-specific factors and forces that are often difficult to change overnight (e.g., political constraints, deep-rooted legal traditions). But if properly implemented they would help unleash the economic potentials and reduce the large income gaps of many developing and emerging countries.

\section{Appendix}

\section{A Modified SDC}

To better understand the properties of the modified SDC contract let the function $R^{B}\left(x_{t}\right)$ denote the state-contingent payment of the bank. The following features characterize the modified SDC (also see Longhofer (1997)):

1. There exists a $\bar{x}_{t}>0$ such that the bankruptcy region is a lower interval, that is, for all $x_{t+1} \geq \bar{x}_{t}$ the entrepreneur is solvent and for all $x_{t+1}<\bar{x}_{t}$ the entrepreneur declares bankruptcy. For convenience, let's call $\bar{x}_{t}$ the solvency cutoff.

2. $R^{B}\left(x_{t+1}\right)=\hat{x}_{t}$, a non-contingent payment if the entrepreneur is solvent, where $\hat{x}_{t}$ is the cutoff return such that $R_{t+1}^{K} l_{t}=\hat{x}_{t} i_{t}$.

3. $R^{B}\left(x_{t+1}\right)=\xi\left(x_{t+1}\right)$ is the maximum (gross) recovery for the bank in bankruptcy states.

To simplify the contracting problem, henceforth I assume that $\xi(x)$ is linear, $\xi(x)=\xi x$ with $\xi \in[0,1]$. This payment function is actually a measure of creditor protection. Creditors 
have no protection if $\xi=0$, partial protection if $0<\xi<1$ and full protection if $\xi=1$, in which case the APR is fully met. The transfer to the entrepreneur in bankruptcy states, $x-\xi(x)$, can be interpreted in the real world as APR violations, legal concessions by the bankruptcy court, or diversion of resources by insiders. ${ }^{14}$

The possibility of partial creditor protection substantially changes the properties of the contracting problem. As Figure 3 illustrates, $\xi<1$ reduces the slope of the function in all bankruptcy states and increases the bankruptcy region. To see this more clearly, note that the solvency cutoff satisfies $\bar{x}=\xi^{-1} \hat{x} \geq \hat{x}$, thus the payment to the bank differs from what would have been the cutoff value under the SDC. Furthermore, the enlarged bankruptcy region can be split into two subintervals, the region up to $\hat{x}$ where bankruptcy occurs because the entrepreneur is unable to repay the debt (region of involuntary default), and the interval between $\hat{x}$ and $\bar{x}$ where the entrepreneur is able to repay the debt but chooses optimally to declare bankruptcy (region of opportunistic default). Partial creditor protection does not restrain strategic default thus weakening the bonding role of debt. Weak creditor protection is also inefficient because it leads to unnecessary (and costly) liquidation of economically viable projects, as in Krasa et al. (2008).

Linearity of the investment technology and the creditor protection function implies that $R_{t+1}^{K}\left(i_{t}-(1-\tau) W_{t}\right)=\hat{x}_{t} i_{t}=\xi \bar{x}_{t} i_{t}$. This allows to define expected payments as linear functions of the project scale, properly measured in units of the consumption good. For the entrepreneur:

$$
\begin{aligned}
& Q_{t+1}\left(\int_{0}^{\bar{x}_{t}}\left(x_{t+1}-\xi x_{t+1}\right) F\left(d x_{t+1}\right)+\int_{\bar{x}_{t}}^{\infty}\left(x_{t+1}-\xi \bar{x}_{t}\right) F\left(d x_{t+1}\right)\right) i_{t} \\
= & Q_{t+1}\left(\mu-\xi \int_{0}^{\bar{x}_{t}} x_{t+1} F\left(d x_{t+1}\right)-\xi \bar{x}_{t}\left[1-F\left(\bar{x}_{t}\right)\right]\right) i_{t} \\
\equiv & Q_{t+1} R^{E}\left(\bar{x}_{t}\right) i_{t}
\end{aligned}
$$

where the first integral is the expected transfer to the entrepreneur in bankruptcy states and the second is the payment in solvency states, net of loan repayment. For the bank:

$$
\begin{aligned}
& Q_{t+1}\left(\int_{0}^{\bar{x}_{t}}\left(\xi x_{t+1}-\kappa x_{t+1}\right) F\left(d x_{t+1}\right)+\int_{\bar{x}_{t}}^{\infty} \xi \bar{x}_{t} F\left(d x_{t+1}\right)\right) i_{t} \\
= & Q_{t+1}\left((\xi-\kappa) \int_{0}^{\bar{x}_{t}} x_{t+1} F\left(d x_{t+1}\right)+\xi \bar{x}_{t}\left[1-F\left(\bar{x}_{t}\right)\right]\right) i_{t} \\
\equiv & Q_{t+1} R^{B}\left(\bar{x}_{t}\right) i_{t},
\end{aligned}
$$

where the first integral is the expected transfer to the bank in bankruptcy states, net of bankruptcy costs, and the second is the loan repayment in solvency states.

The functions $R^{E}\left(\bar{x}_{t}\right)$ and $R^{B}\left(\bar{x}_{t}\right)$ are expected payoffs accruing to the entrepreneur and the bank, respectively, and can be written succintly as follows:

$$
R^{E}\left(\bar{x}_{t}\right)=\mu-\xi B\left(\bar{x}_{t}\right)-\xi \bar{x}_{t}\left(1-F\left(\bar{x}_{t}\right)\right)
$$

\footnotetext{
${ }^{14}$ It may also include unmodeled claims such as taxes and wages that usually have priority over unsecured debt. See Araujo and Funchal (2005) for a cross-country comparison of the priority order of claims in bankruptcy.
} 


$$
R^{B}\left(\bar{x}_{t}\right)=(\xi-\kappa) B\left(\bar{x}_{t}\right)+\xi \bar{x}_{t}\left(1-F\left(\bar{x}_{t}\right)\right),
$$

where $\kappa B\left(\bar{x}_{t+1}\right) \equiv \kappa \int_{0}^{\bar{x}_{t}} x_{t+1} F\left(d x_{t+1}\right)$ is total expected bankruptcy cost.

\section{B Properties of the Loan Contract}

To show the relationship between the cutoff value $\bar{x}_{t}$ and aggregate prices, first use (8) to define the implicit function:

$$
\bar{x}\left(R_{t+1}^{D}, Q_{t+1}\right) \equiv Q_{t+1}\left[R^{B}\left(\bar{x}_{t}\right)+\left(1-\frac{\kappa}{\xi} \bar{x}_{t} h\left(\bar{x}_{t}\right)\right) R^{E}\left(\bar{x}_{t}\right)\right]-R_{t+1}^{D}=0 .
$$

Totally differentiate this function, substitute $R^{B^{\prime}}(\bar{x})$ and $R^{E^{\prime}}(\bar{x})$ and simplify terms to obtain:

$$
\begin{gathered}
\bar{x}_{1}=-\frac{\xi}{\kappa}\left(Q_{t+1} R^{E}\left(\bar{x}_{t}\right) \frac{\partial\left(\bar{x}_{t} h\left(\bar{x}_{t}\right)\right)}{\partial \bar{x}_{t}}\right)^{-1}<0, \\
\bar{x}_{2}=\frac{\xi}{\kappa}\left(Q_{t+1} R^{E}\left(\bar{x}_{t}\right) \frac{\partial\left(\bar{x}_{t} h\left(\bar{x}_{t}\right)\right)}{\partial \bar{x}_{t}}\right)^{-1} \frac{R_{t+1}^{D}}{Q_{t+1}}>0 .
\end{gathered}
$$

To verify the properties of the leverage ratio and loan demand, first rewrite $\psi_{t+1}$ as a function of the ratio $R_{t+1}^{D} / Q_{t+1}$ and substitute (8) into the resulting expression to obtain:

$$
\psi\left(R_{t+1}^{D}, Q_{t+1}\right)=1+\frac{1}{1-(\kappa / \xi) \bar{x}_{t} h\left(\bar{x}_{t}\right)} \frac{R^{B}\left(\bar{x}_{t}\right)}{R^{E}\left(\bar{x}_{t}\right)} \geq 1 .
$$

Second, take the partial derivatives with respect to its two arguments and use the results from (B2) and (B2) to obtain:

$$
\begin{gathered}
\psi_{1}=\psi_{t+1}\left(\psi_{t+1}-1\right)\left(-\frac{1}{R_{t+1}^{D}}+\frac{R^{B^{\prime}}\left(\bar{x}_{t}\right)}{R^{B}\left(\bar{x}_{t}\right)} \bar{x}_{1}\right)<0, \\
\psi_{2}=\psi_{t+1}\left(\psi_{t+1}-1\right)\left(\frac{1}{Q_{t+1}}+\frac{R^{B^{\prime}}\left(\bar{x}_{t}\right)}{R^{B}\left(\bar{x}_{t}\right)} \bar{x}_{2}\right)>0 .
\end{gathered}
$$

The entrepreneurial expected rate of return (11) inherits the properties of $R^{E}\left(\bar{x}_{t}\right)$ and $\psi\left(R_{t+1}^{D}, Q_{t+1}\right)$. It is easy to verify that:

$$
\begin{gathered}
\frac{\partial R_{t+1}^{E}}{\partial R_{t+1}^{D}}=R_{t+1}^{E}\left(\frac{\psi_{1}}{\psi_{t+1}}+\frac{R^{E \prime}\left(\bar{x}_{t}\right)}{R^{E}\left(\bar{x}_{t}\right)} \bar{x}_{1}\right) . \\
\frac{\partial R_{t+1}^{E}}{\partial Q_{t+1}}=R_{t+1}^{E}\left(\frac{1}{Q_{t+1}}+\frac{\psi_{2}}{\psi_{t+1}}+\frac{R^{E}\left(\bar{x}_{t}\right)}{R^{E}\left(\bar{x}_{t}\right)} \bar{x}_{2}\right),
\end{gathered}
$$

Therefore, if the leverage ratio is large enough, the last term in these sentences will be outweighted by the others and $R_{t+1}^{E}$ will be increasing in the price of capital and decreasing in the deposit rate. 
To verify the properties of the lending rate (12), first use the definition of $R_{t+1}^{K}$ and the bank's break even condition:

$$
R_{t+1}^{L}=Q_{t+1} R_{t+1}^{K}=Q_{t+1} \xi \bar{x}_{t} \frac{i_{t}}{i_{t}-W_{t}}=Q_{t+1} \xi \bar{x}_{t} \frac{R_{t+1}^{D}}{Q_{t+1} R^{B}\left(\bar{x}_{t}\right)}=\frac{\xi \bar{x}_{t}}{R^{B}\left(\bar{x}_{t}\right)} R_{t+1}^{D} .
$$

To show that the lending rate is larger than the deposit rate note that:

$$
\begin{aligned}
\frac{R^{B}\left(\bar{x}_{t}\right)}{\xi \bar{x}_{t}} & =\left(1-\frac{\kappa}{\xi}\right) \int_{0}^{\bar{x}_{t}} \frac{x_{t+1}}{\bar{x}_{t}} F\left(d x_{t+1}\right)+\left[1-F\left(\bar{x}_{t}\right)\right] \\
& \leq\left(1-\frac{\kappa}{\xi}\right) \int_{0}^{\bar{x}_{t}} F\left(d x_{t+1}\right)+\left[1-F\left(\bar{x}_{t}\right)\right] \\
& \leq\left(1-\frac{\kappa}{\xi}\right) \int_{0}^{\bar{x}_{t}} F\left(d x_{t+1}\right)+1-F\left(\bar{x}_{t}\right) \\
& =1-\frac{\kappa}{\xi} F\left(\bar{x}_{t}\right) \\
& \leq 1 \\
& \Rightarrow \frac{\xi \bar{x}_{t}}{R^{B}\left(\bar{x}_{t}\right)} \geq 1 .
\end{aligned}
$$

Also note that the term $\xi \bar{x}_{t} / R^{B}\left(\bar{x}_{t}\right)$ approaches $\infty$ with $\bar{x}_{t}$ because $R^{B}\left(\bar{x}_{t}\right)$ is bounded above as shown before. Using this and the Leibniz rule imply that the total effect of the deposit rate is ambiguous and will be positive if $\left|\bar{x}_{1}\right|$ is sufficiently small.

$$
\frac{\partial R_{t+1}^{L}}{\partial R_{t+1}^{D}}=\frac{R_{t+1}^{L}}{R_{t+1}^{D}}\left[1+\left(\frac{\kappa}{\xi} f\left(\bar{x}_{t}\right)+\left(1-\frac{\kappa}{\xi}\right) \frac{B\left(\bar{x}_{t}\right)}{\bar{x}_{t}^{2}}\right) R_{t+1}^{L} \bar{x}_{1}\right] .
$$

However, the impact of the price of capital is unambiguously positive:

$$
\frac{\partial R_{t+1}^{L}}{\partial Q_{t+1}}=\frac{R_{t+1}^{L}}{R_{t+1}^{D}}\left(\frac{\kappa}{\xi} f\left(\bar{x}_{t}\right)+\left(1-\frac{\kappa}{\xi}\right) \frac{B\left(\bar{x}_{t}\right)}{\bar{x}_{t}^{2}}\right) R_{t+1}^{L} \bar{x}_{2}>0
$$

\section{Properties of the Capital Policy Correspondence}

To derive the properties of the law of motion of capital, first note that (24) gives an implicit function relating the deposit rate and the price of capital:

$$
G\left(R^{D}, Q\right) \equiv \eta(1-\tau)\left(\psi\left(R^{D}, Q\right)-1\right)-(1-\eta) s^{H}\left(R^{D}\right)=0 .
$$

Substituting $\psi\left(R^{D}, Q\right)$ and $s^{H}\left(R^{D}\right)$ into this and rearranging terms I obtain:

$$
G\left(R^{D}, Q\right)=\frac{(1-\eta)\left(\beta R^{D}\right)^{\frac{1}{\gamma}}}{\eta(1-\tau)+(1-\tau \eta) \beta^{\frac{1}{\gamma}}\left(R^{D}\right)^{\frac{1-\gamma}{\gamma}}}-Q R^{B}\left(\bar{x}\left(R^{D}, Q\right)\right)=0 .
$$

Using the implicit function theorem and (A1)-(A2) I find:

$$
\frac{d R^{D}}{d Q}=-\frac{G_{2}}{G_{1}}=H\left(R^{D}, Q ; \gamma\right) \frac{R^{D}}{Q}>0
$$


where

$$
H\left(R^{D}, Q ; \gamma\right) \equiv \frac{R^{B}(\bar{x})-R^{B \prime}(\bar{x}) \bar{x}_{1} R^{D}}{\varphi R^{B}(\bar{x})-R^{B \prime}(\bar{x}) \bar{x}_{1} R^{D}} \gtrless 1 \Leftrightarrow \gamma \gtrless 1
$$

and

$$
\varphi \equiv \frac{\eta(1-\tau) R^{D} / \gamma+(1-\tau \eta)\left(\beta R^{D}\right)^{\frac{1}{\gamma}}}{\eta(1-\tau) R^{D}+(1-\tau \eta)\left(\beta R^{D}\right)^{\frac{1}{\gamma}}} \gtrless 1 \Leftrightarrow \gamma \lessgtr 1 .
$$

Now define the function:

$$
J(Q)=\left[\mu-\kappa B\left(\bar{x}\left(R^{D}(Q), Q\right)\right)\right]\left[\eta(1-\tau)+(1-\eta) s^{H}\left(R^{D}(Q)\right)\right]
$$

and substitute in (21) to obtain:

$$
\left.K_{t+1}=J\left(Q_{t+1}\right)(1-\alpha)\right] \backslash K_{t}^{\alpha} .
$$

The derivative of $J$ with respect to $Q$ is given by:

$$
J^{\prime}(Q)=\left(H J^{S}+(H-1) J^{I}\right) \frac{R^{D}}{Q},
$$

where

$$
J^{S} \equiv[\mu-\kappa B(\bar{x})](1-\eta) s^{H^{\prime}}\left(R^{D}\right) \gtrless 0 \Leftrightarrow \gamma \lessgtr 1
$$

and

$$
J^{I} \equiv-\kappa\left[\eta(1-\tau)+(1-\eta) s^{H}\left(R^{D}\right)\right] \bar{x} f(\bar{x}) \bar{x}_{1}>0
$$

are related to the elasticity of savings and investment to the interest rate, respectively. Or, alternatively, to the elasticity of loan supply and loan demand curves (see Figure 5). These two terms illustrate that the sign of $J^{\prime}(Q)$ will ultimately depend on the value of $\gamma$. It can be also checked that $J$ is bounded above and below, $(1-\kappa)(1-\tau) \eta \mu<J(Q)<(1-\tau \eta) \mu$. Finally, taking (16) into account, the derivative of next period's capital $K_{t}$ is:

$$
\frac{d K_{t+1}}{d K_{t}}=\frac{\alpha J\left(Q_{t+1}\right)}{J\left(Q_{t+1}\right)+(1-\alpha) Q_{t+1} J^{\prime}\left(Q_{t+1}\right)}\left(\frac{K_{t+1}}{K_{t}}\right) .
$$

This derivative is clearly positive if one of the following three cases hold. The first case (baseline) requires $\gamma<1$ and $H J^{S}>\left|(H-1) J^{I}\right|$, that is, household savings are increasing in the deposit rate and savings are more sensitive to the interest rate than investment. Although $\gamma<1$ may be seem as a restrictive assumption on preferences, Galor and Ryder (1989) have shown that $s^{H \prime}\left(R^{D}\right)>0$ is a necessary condition for uniqueness and stability of the steady state. Second, $\gamma>1$ and $\left|H J^{S}\right|<(H-1) J^{I}$ and investment is more sensitive to the interest rate than savings. Finally, $J^{\prime}(Q)$ is negative but $J(Q)>\left|Q J^{\prime}(Q)\right|$, i.e., the price elasticity of the capital stock is relatively small.

The numerical simulations in Section 5 illustrate that assuming reasonable values for the key parameters $\gamma, \kappa, \tau$ and $\xi$ and ruling out solutions where $\bar{x}>x^{*}$ imply that the capital policy correspondence must cross the $45^{\circ}$ line from above at least once, which ensures the existence of at least one positive and locally stable steady state. The policy correspondence would have to be strictly concave in its entire domain for uniqueness and global stability, but this would require even more restrictive assumptions on preferences and possibly additional restrictions on the hazard rate. 
For instance, in the special case of logarithmic preferences conditions (8) and (24) imply a cutoff productivity that is independent of aggregate prices and a constant $J=[\mu-$ $\kappa B(\bar{x})](\eta(1-\tau)+(1-\tau \eta) \beta) /(1+\beta)$. Consequently, the capital policy correspondence would satisfy the usual Inada conditions required for a globally unique and stable steady state.

\section{Alternative Deposit Supply Function}

This appendix assesses the responses of the economy to the three distortions when the interest rate-elasticity of the deposit supply is unity (i.e., logarithmic preferences) and 2 . If $\gamma=1$, the household savings rate converges to $\beta /(1+\beta)$, and the deposit supply becomes perfectly inelastic (Figure 5, third panel). Combining equations (8), (10) and (24) implies that the solvency cutoff $\bar{x}$ becomes independent of aggregate prices:

$$
\frac{R^{B}(\bar{x})}{R^{E}(\bar{x})\left(1-\frac{\kappa}{\xi} \bar{x} h(\bar{x})\right)}=\frac{(1-\eta) \beta}{\eta(1-\tau)(1+\beta)},
$$

and so does the leverage ratio. This implies that the credit-to-output ratio in (25) converges to a constant that is independent of any distortions:

$$
L^{Y}=\frac{(1-\alpha)(1-\eta) \beta}{1+\beta} .
$$

Hence, the response of output per capita is smaller than under the baseline, but the impact on lending spreads is not neutral as it is still affected by the behavior of the solvency cutoff. In fact, the response of spreads is slightly larger than in the baseline (Figure 11, dashed blue lines).

When $\gamma>1$, savings are decreasing in the deposit rate, and the deposit supply is downward-sloping (Figure 5, first panel). Mechanically, higher costs of doing business and resolving insolvency (lower creditor protection) will reduce (increase) the deposit rate and the price of capital. But the deposit rate will decline (rise) by less than the price of capital, and so the ratio $R^{D} / Q$ will increase (decrease) in equilibrium, thereby boosting corporate leverage and credit (also see Appendix B). This counterintuitive reaction of financial intermediation will mitigate the impact on output or even lead to some output gains relative to the baseline. On the other hand, the solvency cutoff will rise in response of $R^{D} / Q$ so that banks still break even in equilibrium and this will culminate in higher default rate and lending spreads compared to the baseline (Figure 11, dotted red lines).

Beyond the inner workings of the model, this exercise illustrates two important points. First, financial sector outcomes reflect complex interactions between depositors' behavior, corporate financing structure, and distortions in the financial and real sectors of the economy. Second, correct identification of the underlying distortions and design of appropriate policies to eliminate them would require deep understanding of country-specific circumstances as well as learning from cross-country experiences. Researchers and policy-makers would need to assess a broad range of macro and microeconomic indicators, including measures of financial development and financial stability, legal foundations of debt contracts, and the modus operandi of the bankruptcy and judicial systems. 


\section{References}

Acharya, V. and K. Subramanian (2009) Bankruptcy Codes and Innovation. The Review of Financial Studies, Vol. 22, Issue 12, pp. 4949-4988.

Antunes, A. and T. Cavalcanti, A. Villamil (2010) Intermediation Costs and Welfare. Center for Growth \&G Business Cycle Research Discussion Paper Series, No. 142.

Araujo, A. and B. Funchal (2005) Past and Future of the Bankruptcy Law in Brazil and Latin America. Ensaios Economicos, No. 599.

Araujo, A. and R. Ferreira, B. Funchal, (2012) The Brazilian Bankruptcy Law Experience. Journal of Corporate Finance, Vol. 18, Issue 4, pp. 994-1004.

Azariadis, C. and S. Chakraborty (1999) Agency Costs in Dynamic Economic Models. The Economic Journal, 109, pp. 222-241.

Barseghyan, L. (2008) Entry Costs and Cross-Country Differences in Productivity and Output. Journal of Economic Growth, Vol. 13, Issue 2, pp. 145.167.

Bebchuck, L.A. (2002) Ex-Ante Costs of Violating Absolute Priority Rule in Bankruptcy. The Journal of Finance, Vol. 57, No. 1, pp. 445-460.

Beck, T. and R. Levine (2005) Legal Institutions and Financial Development. In C. Menarde and M. Shirley (eds.), Handbook of New Institutional Economics, pp. 251-278. Springer.

Bergoeing, R. and P. Kehoe, T. Kehoe, R. Soto (2002) A Decade Lost and Found: Mexico and Chile in the 1980s. Review of Economic Dynamics, Vol. 5, Issue 1, pp. 166-205.

Berkowitz, J. and M.J. White (2004) Bankruptcy and Small Firms' Access to Credit. RAND Journal of Economics, Vol. 35, No. 1, pp. 69-84.

Bernanke, B. and M. Gertler (1989) Agency Costs, Net Worth, and Business Fluctuations. The American Economic Review, Vol. 79, No. 1, pp. 14-31.

Bernanke, B. and M. Gertler, S. Gilchrist (1999) The Financial Accelerator in a Quantitative Business Framework. In J. B. Taylor and M. Woodford (eds.), Handbook of Macroeconomics, Edition 1, Vol. 1, No. 1, Ch. 1, pp. 1341-1393. Elsevier.

Boyd, J. and B. Smith (1994) How Good Are Standard Debt Contracts? Stochastic Versus Nonstochastic Monitoring in a Costly State Verification Environment. The Journal of Business, Vol. 67, No. 4, pp. 539-561.

Carlstrom, C. and T. Fuerst (1997) Agency Costs, Net Worth, and Business Fluctuations: A Computable General Equilibrium Analysis. The American Economic Review, Vol. 87, No. 5, pp. 893-910.

Castro, R. and G.L. Clementi, G. MacDonald (2004) Investor Protection, Optimal Incentives, and Economic Growth. The Quarterly Journal of Economics, Vol. 119, Issue 3, pp. 11311175 . 
Chatterjee, S. and D. Corbae, N. Nakajima, J. Ríos-Rull (2007) A Quantitative Theory of Unsecured Consumer Credit with Risk of Default. Econometrica, Vol. 75, No. 6, pp. 15251589.

Chiappori, P-A. and M. Paiella (2011) Relative Risk Aversion is Constant: Evidence from Panel Data. Journal of European Economic Association, Vol. 9, Issue 6, pp. 1021-1052.

Christiansen, L. and M. Schindler, T. Tressel (2013) Growth and Structural Reforms: A New Assessment. Journal of International Economics, 89, pp. 347-356.

Ciccone, A. and E. Papaioannou (2007) Red Tape and Delayed Entry. Journal of the European Economic Association, Vol. 5, Issue 2-3, pp. 444-458.

Claessens, S. and S. Djankov, T. Nenova (2000) Corporate Risk Around the World. World Bank Policy Research Working Paper, No. 2271.

Cooley, T. and R. Marimon, V. Quadrini (2003) Aggregate Consequences of Limited Contract Enforceability. NBER Working Paper, No. 10132.

Dabla-Norris, E. and G. Ho, K. Kochhar, A. Kyobe, R. Tchaidze (2013) Anchoring Growth: The Importance of Productivity-Enhancing Reforms in Emerging Market and Developing Economies. IMF Staff Discussion Note, SDN/13/08.

Divanbeigi, R. and R. Ramalho (2015) Business Regulations and Growth. World Bank Policy Research Working Paper, No. 7299.

Djankov, S. and C. McLiesh, A. Shleifer (2007) Private Credit in 129 Countries. Journal of Financial Economics, 89, pp. 299-329.

Doing Business 2017 Equal Opportunity for All. World Bank, Washington D.C.

Dreher, A. and T. Herzfeld (2005) The Economic Costs of Corruption: A Survey and New Evidence. https://papers.ssrn.com/sol3/papers.cfm?abstract_id=734184.

Dubey, P. and J. Geanakoplos, M. Shubik (2005) Default and Punishment in General Equilibrium. Econometrica, Vol. 73, No. 1, pp. 1-37.

Galor, O. and H. Ryder (1989) Existence, Uniqueness, and Stability of Equilibrium in a Overlapping-Generations Model with Productive Capital. Journal of Economic Theory, Vol. 49, Issue 2, pp. 360-375.

Gale, D. and M. Hellwig (1985) Incentive-Compatible Debt Contracts: The One-Period Problem. The Review of Economic Studies, Vol. 52, No. 4, pp. 647-663.

Gentry, W. and G. Hubbard (2004) Entrepreneurship and Household Saving. Advances in Economic Analysis \& Policy, Vol. 4, Issue 1, Article 8.

Gitlin, R. and B. House (2015) Just Enough, Just in Time Improving Sovereign Debt Restructuring for Creditors, Debtors and Citizens Special Report. Centre for International Governance Innovation. 
Haidar, J. (2012) The Impact of Business Regulatory Reform on Economic Growth. Journal of the Japanese and International Economies, Vol. 26, Issue 3, pp. 285-307.

Hart, O. (1995) Firms, Contracts, and Financial Structure. Oxford University Press.

Headd, B. (2003) Redefining Business Success: Distinguishing Between Closure and Failure. Small Business Economics, Vol. 21, No. 1, pp. 51-61.

International Monetary Fund (2013) Sovereign Debt Restructuring-Recent Developments and Implications for the Fund's Legal and Policy Framework. Washington, D.C., April 2013.

International Monetary Fund (2014) The Fund's Lending Framework and Sovereign DebtPreliminary Considerations. Washington, D.C., June 2014.

International Monetary Fund (2015) Reforming the Fund's Policy on Non-Toleration of Arrears to Official. Washington, D.C., December 2015.

International Monetary Fund (2016) The Fund's Lending Framework and Sovereign DebtFurther Considerations. Washington, D.C., January 2016.

Japelli, T. and M. Pagano, M. Bianco (2005) Courts and Banks: Effects of Judicial Enforcement on Credit Markets. Journal of Money, Credit and Banking, Vol. 37, No. 2, pp. 223-244.

Kaplan, S. and A. Schoar (2005) Private Equity Performance: Returns, Persistence, and Capital Flows. The Journal of Finance, Vol. 60, No.4, pp. 1791-1823.

Kaplan, D. and E. Piedra, E. Seira (2011) Entry Regulation and Business Start-Ups: Evidence from Mexico. Journal of Public Economics, Vol. 95, Issues 11-12, pp. 1501-1515.

Klapper, L. and L. Laeven, R. Rajan, (2006) Entry Regulation as a Barrier to Entrepreneurship. Journal of Financial Economics, Vol. 83, Issue 3, pp. 591-629.

Krasa, S. and T. Sharma, A. Villamil (2008) Bankruptcy and Firm Finance. Economic Theory, Vol. 36, Issue 2, pp. 239-266.

Krueger, A. (2002) A New Approach to Sovereign Debt Restructuring. International Monetary Fund, Washington, D.C., April 2002.

Levine, R. (2005) Finance and Growth: Theory and Evidence. In P. Aghion and S. Durlauf (eds.), Handbook of Economic Growth, Volume 1A, Chapter 12, pp. 865-934. North Holland.

Longhofer, S. (1997) Absolute Priority Rule Violations, Credit Rationing, and Efficiency. Journal of Financial Intermediation, 6, pp. 249-267.

Longhofer, S. and C. Carlstrom (1997) Absolute Priority Rule Violations in Bankruptcy. Federal Reserve Bank of Cleveland Economic Review, Issue Q IV, pp. 21-30.

Lucas, R. (2003) Macroeconomic Priorities. The American Economic Review, Vol. 93, Issue 1 , pp. 1-14. 
Monteiro, J. and J. Assuncao (2011) Coming Out of the Shadows? Estimating the Impact of Bureaucracy Simplification and Tax Cut on Formality in Brazilian Microenterprises. Journal of Development Economics, Vol. 99, Issue 1, pp. 105-115.

Moskowitz, T. and A. Vissing-Jorgensen (2002) The Returns to Entrepreneurial Investment: A Private Equity Premium Puzzle? The American Economic Review, Vol. 92, No. 4, pp. 745-778.

Phillips, B. and B. Kirchhoff (1989) Formation, Growth and Survival; Small Firm Dynamics in the U.S. Economy. Small Business Economics, Vol. 1, No. 1, pp. 65-74.

Prescott, E. (2002) Prosperity and Depression. The American Economic Review, Vol. 92, Issue 1, pp. $1-15$.

Rodriguez-Delgado, J. D. (2010) Bankruptcy and Firm Dynamics: The Case of the Missing Firms. IMF Working Paper, No. 10/41.

Singer, S. and J. Amoros, D. Arreola (2014) Global Entrepreneurship Monitor-2014 Global Report.

Souza-Sobrinho, N. (2010) Macroeconomic of Bank Interest Spreads: Evidence from Brazil. Annals of Finance, Vo. 6, Issue 1, pp. 1-32.

Townsend, R. (1979) Optimal Contracts and Competitive Markets with Costly State Verification. Journal of Economic Theory, 21, pp. 265-293. 


\section{Table 1. Cost of Doing Business and Bankruptcy Technology Across Countries}

\begin{tabular}{lccc}
\hline Transaction & Bottom quartile & Median & Top quartile \\
\hline Running a Business 1/ & & & \\
$\quad$ Starting a business & 0.21 & 0.87 & 2.17 \\
$\quad$ Dealing with construction permits & 0.76 & 2.00 & 5.48 \\
$\quad$ Getting electricity & 1.39 & 6.46 & 16.85 \\
$\quad$ Registering property & 2.59 & 5.00 & 7.60 \\
$\quad$ Enforcing contracts & 0.88 & 1.16 & 1.49 \\
$\quad$ All five combined 2/ & 9.67 & 17.22 & 34.92 \\
Bankruptcy Cost & & & \\
$\quad$ Cost of resolving insolvency 3/ & 0.09 & 0.15 & 0.21 \\
Creditor Protection & & & \\
$\quad$ Recovery rate 4/ & 0.27 & 0.37 & 0.50 \\
\hline
\end{tabular}

Source: World Bank's Doing Business 2015-2017, sample of 124 countries. See http://www.doingbusiness.org/.

1 / Each component is expressed in percent of the business' value.

2/ Expressed in percent of the business' assets.

3/ Sum of the five components of Doing Business, properly adjusted as a fraction of enterprise's value.

4/ Used in the paper as proxy for creditor protection. It is defined as cents on the dollar recouped by secured creditors through reorganization, liquidation or debt enforcement proceedings.

\section{Table 2. Baseline Parameters}

\begin{tabular}{lcc}
\hline Parameter & Symbol & Value \\
\hline Capital income share & $\alpha$ & 0.40 \\
Fraction of entrepreneurs & $\eta$ & 0.15 \\
Risk aversion coefficient & $\gamma$ & 0.50 \\
Discount factor & $\beta$ & 0.80 \\
Mean return of capital projects & $\mu$ & 1.60 \\
Volatility of returns & $\sigma$ & 0.80 \\
Mean of the normal distribution & $\mu_{\mathrm{x}}$ & 0.35 \\
Standard deviation of the normal & $\sigma_{\mathrm{x}}$ & 0.47 \\
Cost of running a business & $\tau$ & 0.10 \\
Bankruptcy cost & $\mathrm{\kappa}$ & 0.20 \\
Creditor protection & $\xi$ & 1.00 \\
\hline
\end{tabular}

Note: Discount factor, average returns and standard deviations are consistent with decennial data. 


\section{Figure 1. Cost of Doing Business, Bankruptcy Technology and Economic Outcomes}
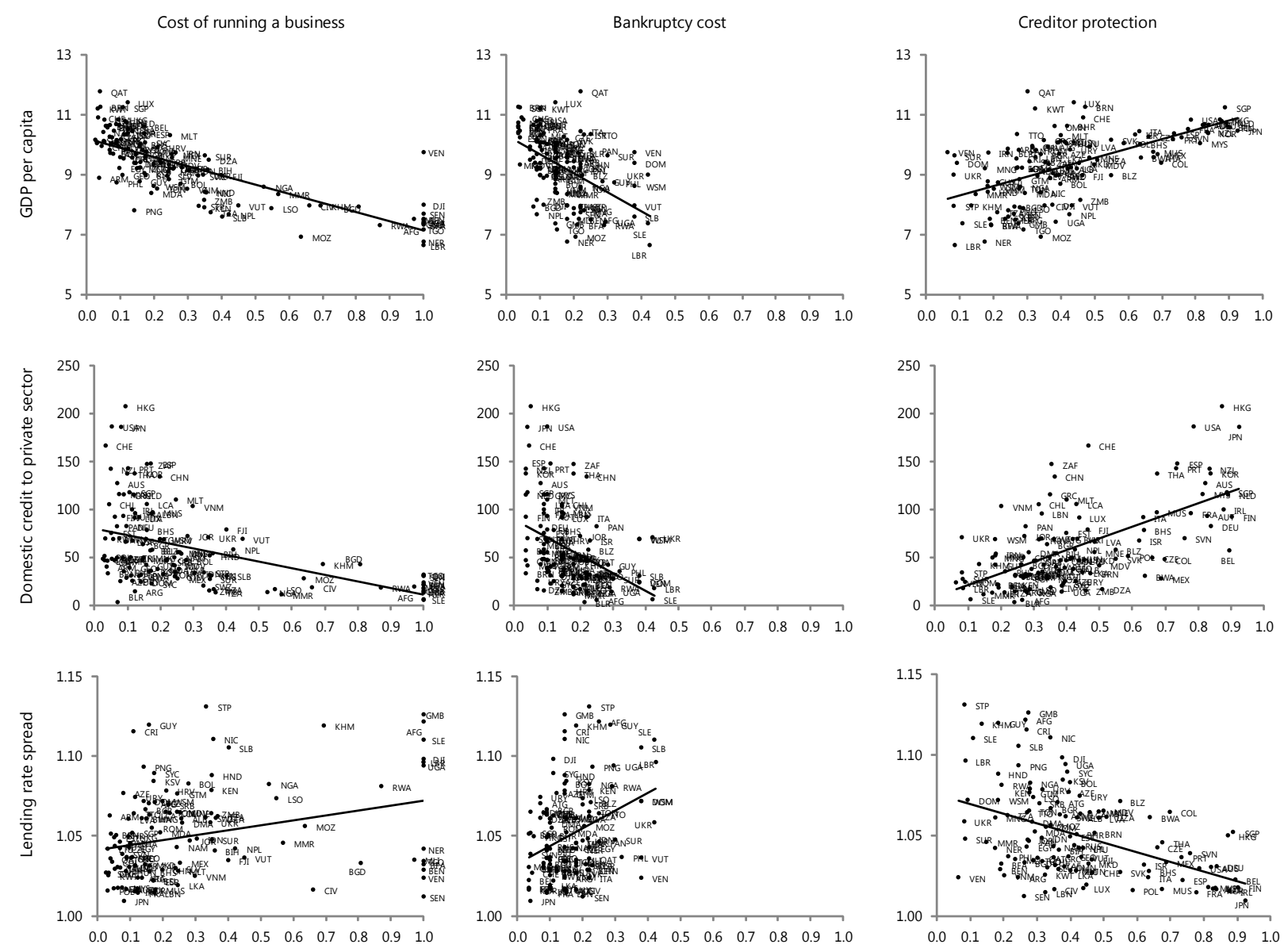

Sources: Doing Business, Global Financial Development, World Development Indicators, International Financial Statistics; and author's calculations. Macro data are averages for 2010-15, and business indicators are averages for the three latest available years, and cover 124 countries with available data, after eliminating outliers.

Note: The scatterplots in each column show the association between the costs of running a business, the costs of resolving bankruptcy, and creditor rights, respectively, and the three macroeconomic indicators on the vertical axes: real GDP per capita, expressed in logs and originally calculated at PPP basis and measured in 2011 international dollars; domestic credit to private sector, expressed as a percent of GDP; and lending interest spread is measured as the ratio between the lending rate and the deposit rate. The solid lines are linear fitting curves.

\section{Figure 2. Sequence of Events for Time- $t$ Young Cohorts}

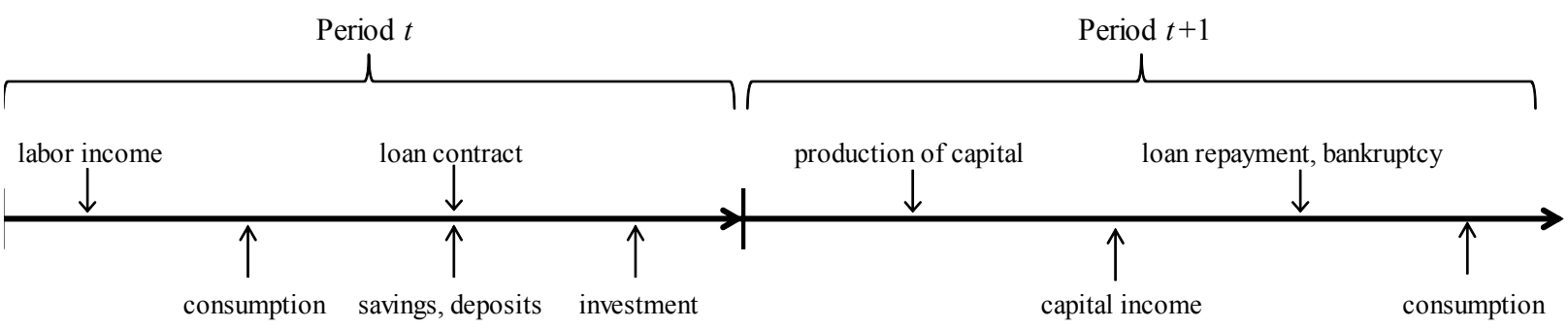


Figure 3. Payment Function of the Bank
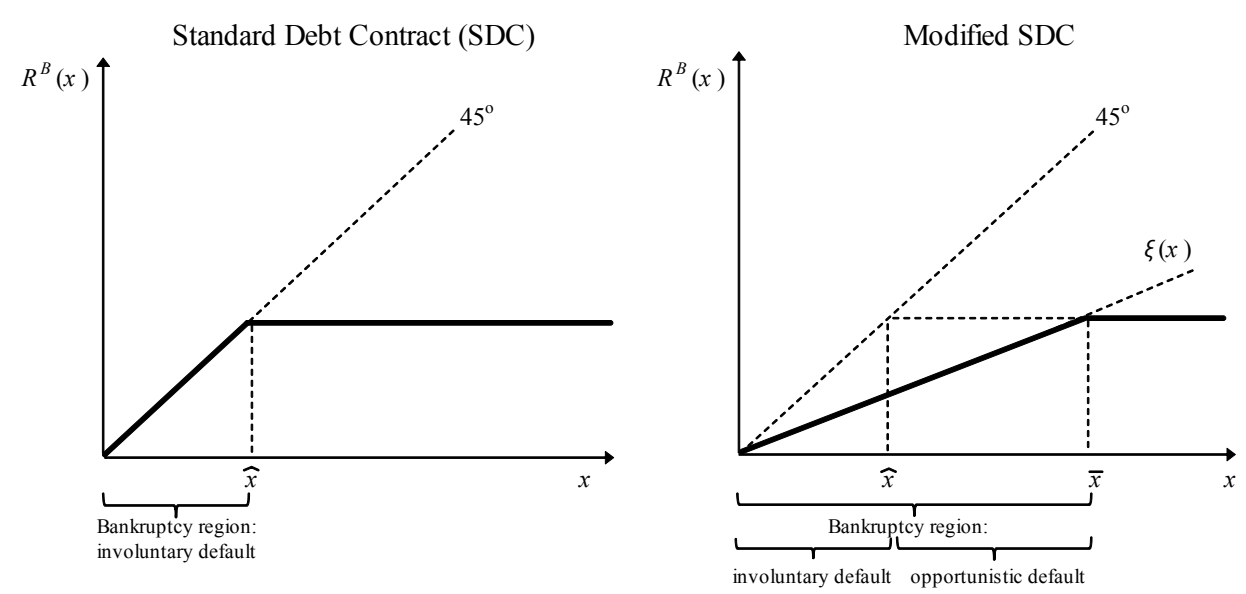

Figure 4. Expected Payoffs (case of unit investment)
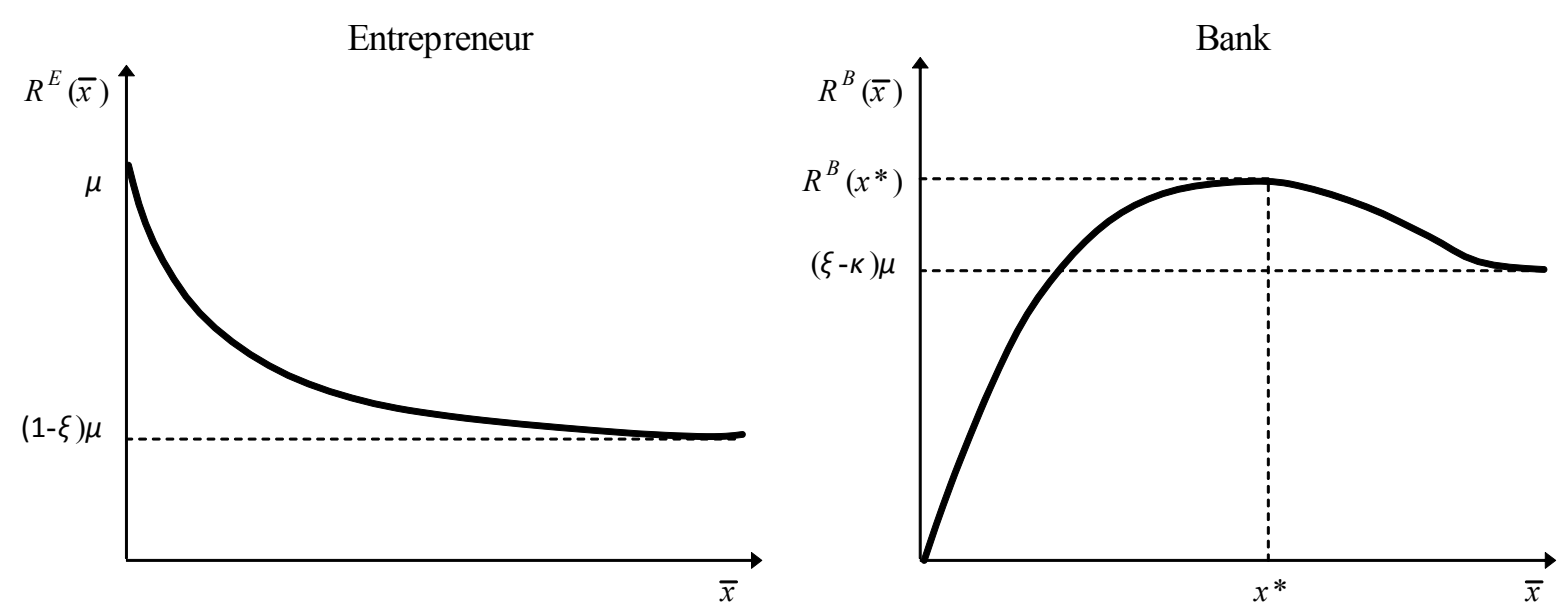

Figure 5. Credit Market Equilibrium (case of unit wage rate)
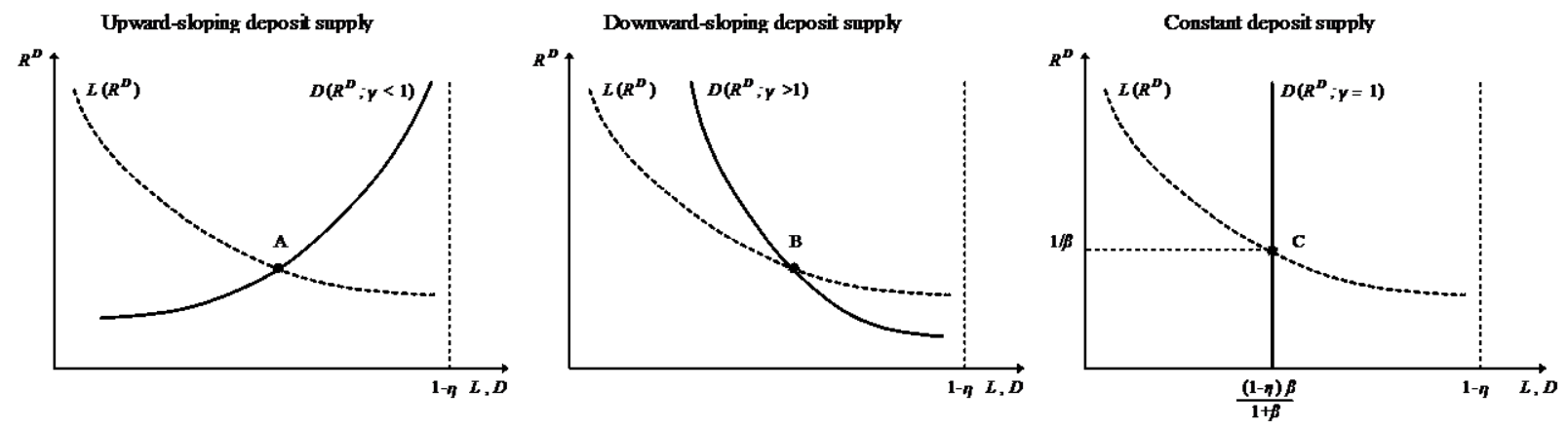
Figure 6. Marginal Effects of the Cost of Running a Project ( $\tau$ ), Bankruptcy Cost $(\kappa)$, and Creditor Protection $(\xi)$ on Output, Credit and Spread

(deviations from benchmark)
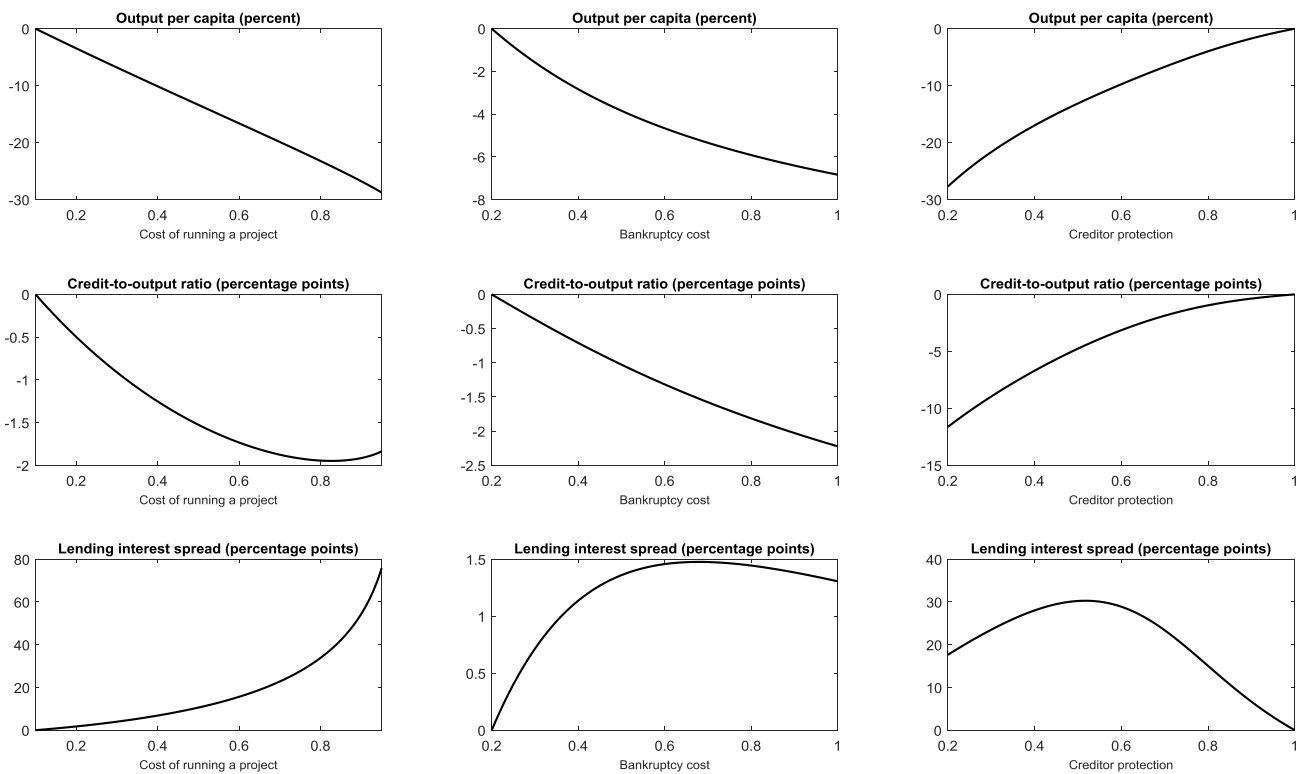

Figure 7. Welfare Effects

(deviations from benchmark)
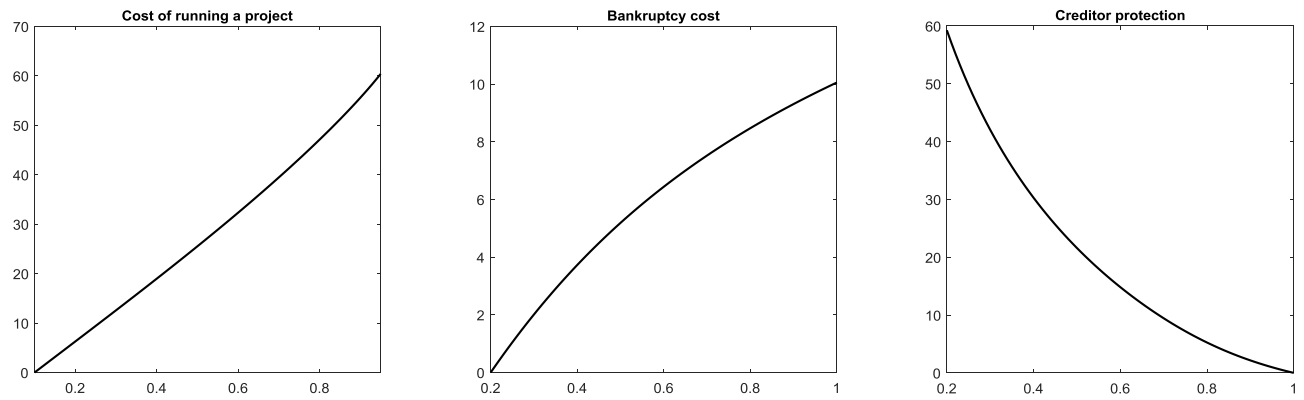


\section{Figure 8. Interactions}

(deviations from benchmark)
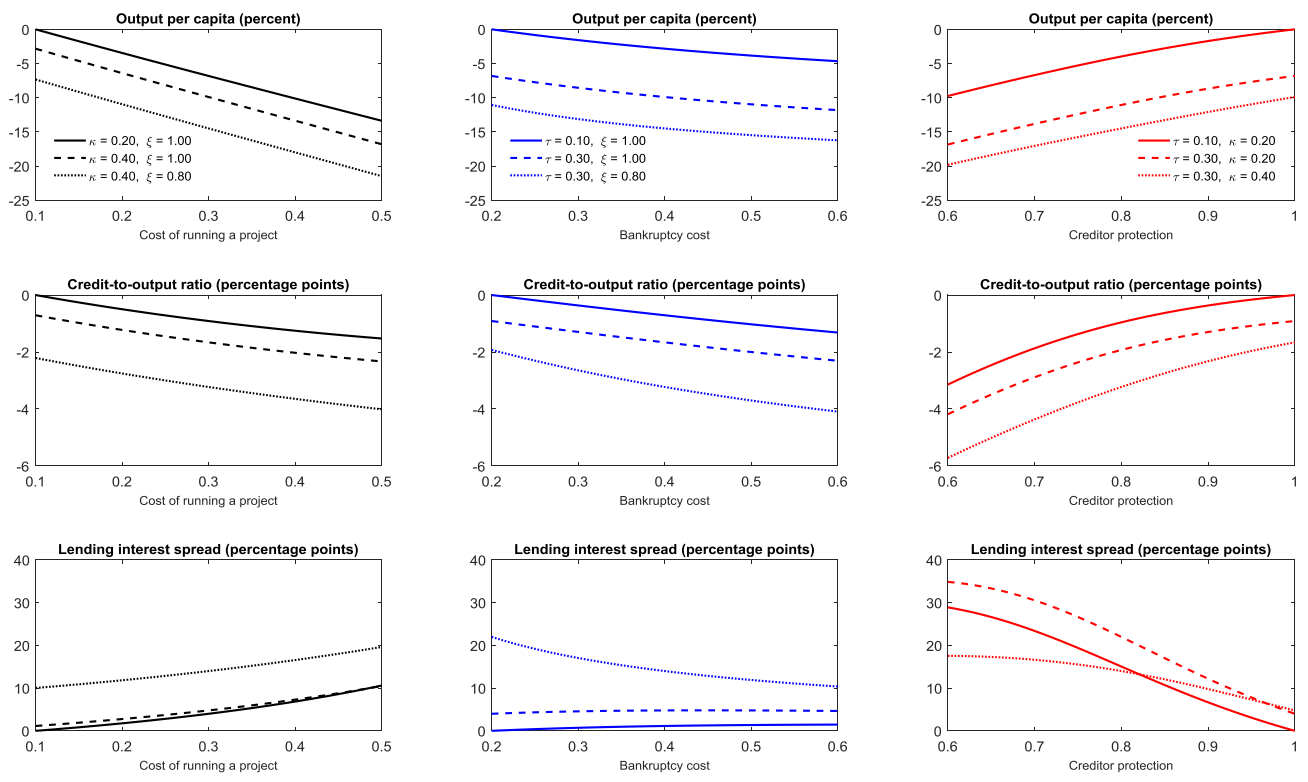

Figure 9. Equilibrium with Alternative Savings Instrument (deviation from benchmark)
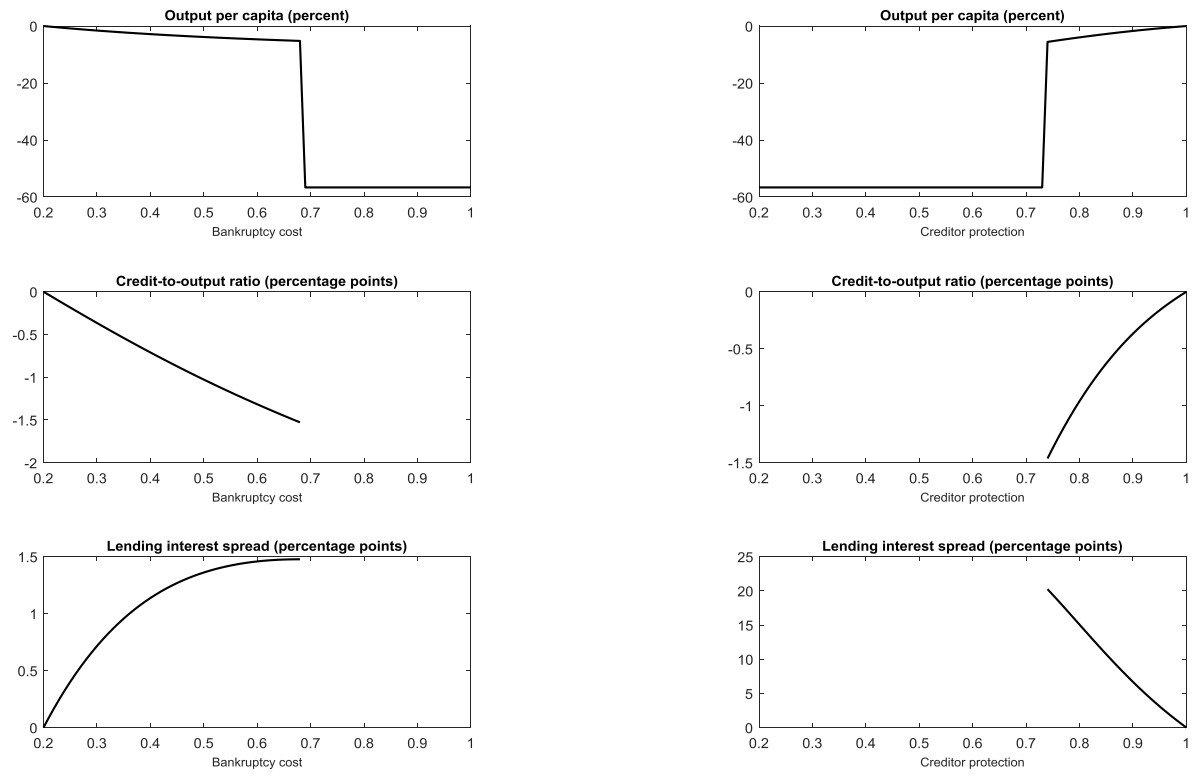

Note: The simulation for bankruptcy cost assumes: $\tau=0.1$ and $\xi=1$; for creditor protection: $\tau=0.1$ and $\kappa=0.2$; and for both $R^{A}=1.0$. 
Figure 10. Equilibrium with a "Floor" on the Deposit Rate (deviation from benchmark)
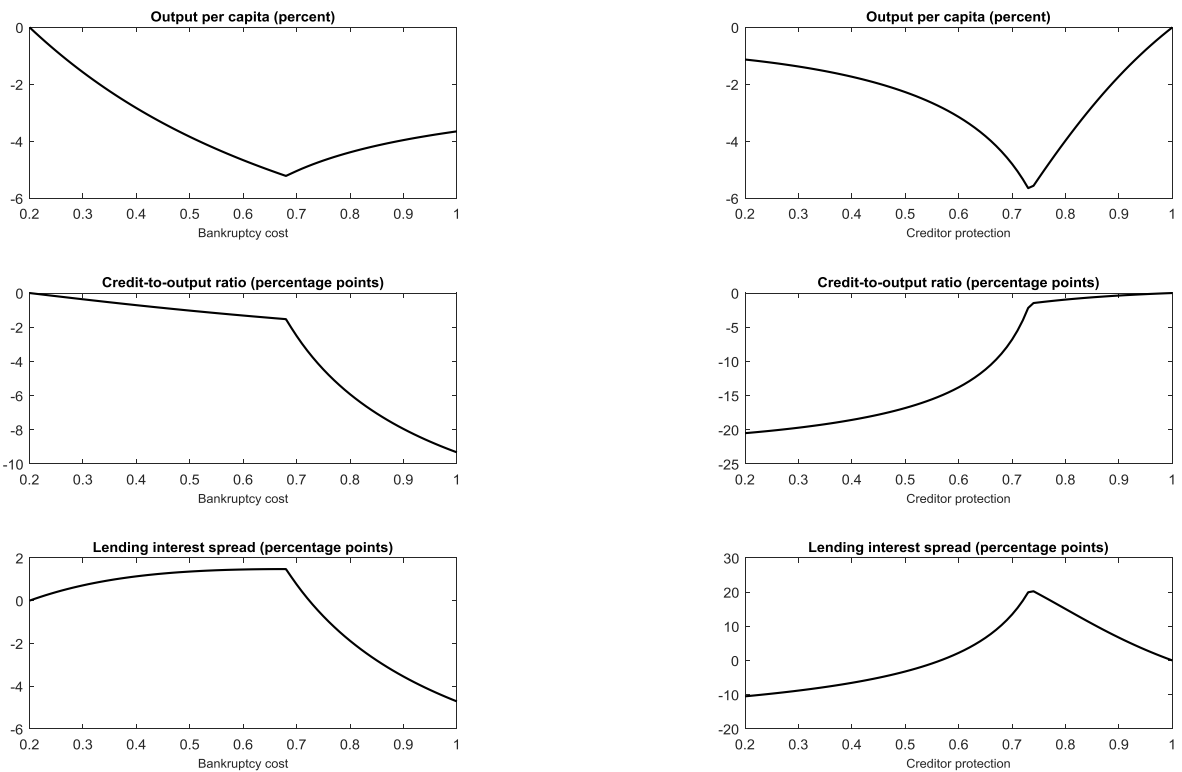

Note: The simulation for bankruptcy cost assumes: $\tau=0.1$ and $\xi=1$; for creditor protection: $\tau=0.1$ and $\kappa=0.2$; and for both $R^{A}=1.0$.

\section{Figure 11. Sensitivity to the Deposit Supply Function}

(deviation from benchmark)
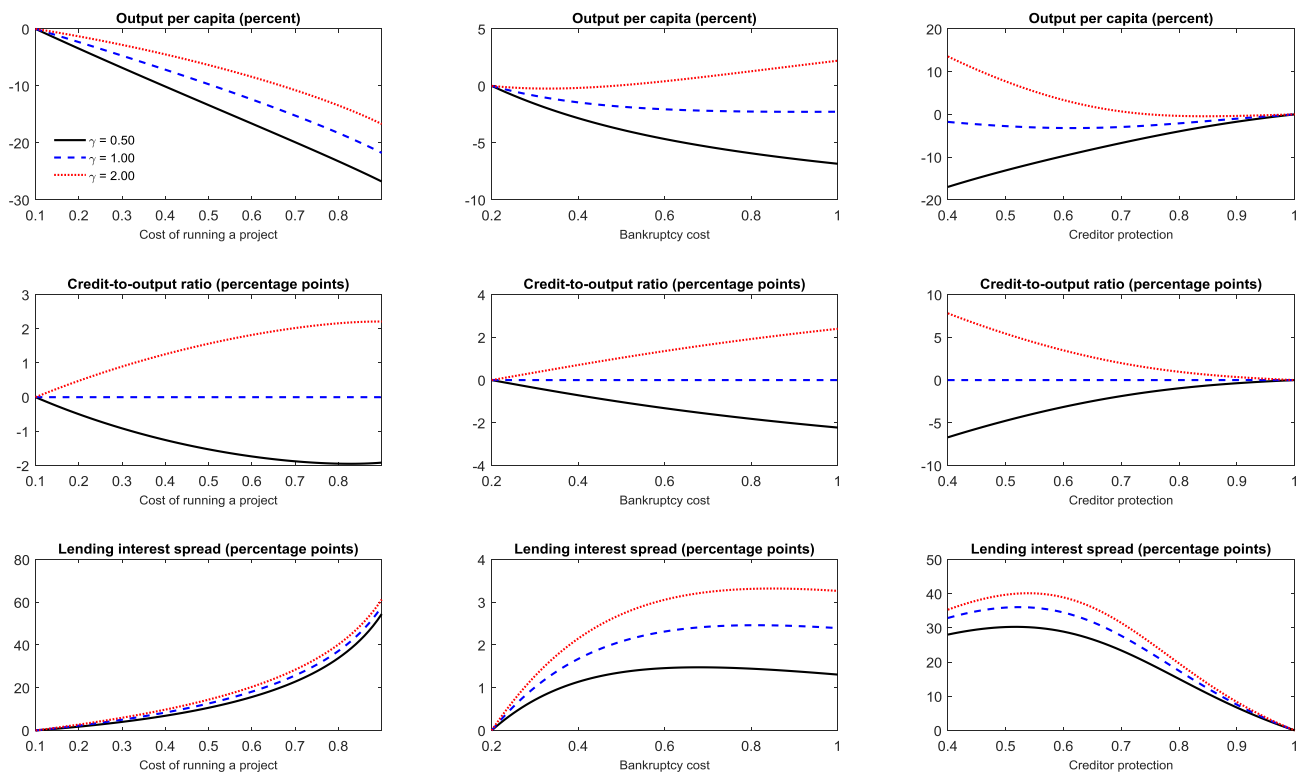